\title{
Abrogating $\mathrm{Cbl}-\mathrm{b}$ in effector CD8+ T cells improves the efficacy of adoptive therapy of leukemia in mice
}

\author{
Ingunn M. Stromnes, ${ }^{1}$ Joseph N. Blattman, ${ }^{1,2}$ Xiaoxia Tan, ${ }^{1}$ Sara Jeevanjee, ${ }^{2}$ \\ Hua Gu, ${ }^{3}$ and Philip D. Greenberg ${ }^{1,2,4}$

\begin{abstract}
${ }^{1}$ Department of Immunology, University of Washington, Seattle, Washington, USA. ${ }^{2}$ Program in Immunology, Fred Hutchinson Cancer Research Center, Seattle, Washington, USA. ${ }^{3}$ Department of Microbiology, Columbia University, New York, New York, USA. ${ }^{4}$ Department of Medicine (Oncology),
\end{abstract} \\ University of Washington, Seattle, Washington, USA.
}

\begin{abstract}
The clinical use of adoptive immunotherapy with tumor-reactive $\mathrm{T}$ cells to treat established cancers is limited in part by the poor in vivo survival and function of the transferred $T$ cells. Although administration of exogenous cytokines such as IL-2 can promote $T$ cell survival, such strategies have many nonspecific activities and are often associated with toxicity. We show here that abrogating expression of Casitas B-lineage lymphoma b (Cbl-b), a negative regulator of lymphocyte activation, in tumor-reactive $\mathrm{CD8}^{+} \mathrm{T}$ cells expanded ex vivo increased the efficacy of adoptive immunotherapy of disseminated leukemia in mice. Mechanistically, Cbl-b abrogation bypassed the requirement for exogenous IL-2 administration for tumor eradication in vivo. In addition, $\mathrm{CD8}^{+} \mathrm{T}$ cells lacking Cbl-b demonstrated a lower threshold for activation, better survival following target recognition and stimulation, and enhanced proliferative responses as a result of both IL-2-dependent and -independent pathways. Importantly, siRNA knockdown of Cbl-b in human $\mathrm{CD8}^{+} \mathrm{CD}^{28}{ }^{-}$effector $\mathrm{T}$ cell clones similarly restored IL-2 production and proliferation following target recognition independent of exogenous IL-2, enhanced IFN- $\gamma$ production, and increased target avidity. Thus, abrogating Cbl-b expression in effector $\mathrm{T}$ cells may improve the efficacy of adoptive therapy of some human malignancies.
\end{abstract}

\section{Introduction}

Adoptive transfer of ex vivo expanded tumor-specific $\mathrm{CD}^{+} \mathrm{T}$ cells has exhibited efficacy in the treatment of some malignant diseases (1-6). However, substantive obstacles to making T cell therapy reproducibly effective remain, including isolating high-avidity tumor-reactive $\mathrm{T}$ cells and sustaining the in vivo survival and function of transferred cells. T cell persistence can be transiently maintained by the administration of IL-2 (2, 7-9), but this is often associated with significant toxicity in humans and may also undesirably promote expansion of Tregs (10). The poor T cell function often observed in therapy has been more difficult to address, as it, in part, reflects deficient expression of costimulatory proteins and/or increased expression of inhibitory ligands or suppressive cytokines by tumor cells $(4,11)$. The low avidity of most potentially tumor-reactive $\mathrm{T}$ cells, which can lead to inefficient recognition and elimination of tumor cells, appears to be intrinsic to targeting tumor antigens, as most tumor antigens are "self" proteins aberrantly expressed or overexpressed by the tumor. Thus, strategies to improve $T$ cell survival, function, and avidity are needed, and one approach is to manipulate the intrinsic properties of $\mathrm{T}$ cells by genetic modification prior to transfer.

The $\mathrm{E} 3$ ubiquitin ligase, Casitas B-lineage lymphoma b (Cbl-b), is a negative regulator of lymphocyte function (12-15). Cbl-b increases the threshold for naive $\mathrm{T}$ cell activation by regulating TCR and CD28 signaling, in part by inhibiting PKC $\theta$ - and PI3K/Akt-dependent pathways, respectively (16-20). Abrogating Cbl-b expression

Authorship note: Ingunn M. Stromnes and Joseph N. Blattman contributed equally to this work.

Conflict of interest: The authors have declared that no conflict of interest exists. Citation for this article: J Clin Invest. 2010;120(10):3722-3734. doi:10.1172/JCI41991. rescues IL-2 production and proliferation by naive $\mathrm{CD} 28^{-/-} \mathrm{T}$ cells $(16,17)$, which has therapeutic implications, since CD28 expression is often lost on $\mathrm{T}$ cells that have differentiated to effector cells during repetitive stimulations in vitro. Our laboratory has demonstrated that reconstitution of CD28 expression in human effector T cells restores autocrine IL-2 production and proliferation (21), indicating that the intracellular pathways required for IL-2 production remain accessible and functional in effector cells. However, often tumors lack expression of the costimulatory proteins that bind CD28, which may preclude this approach. Thus, disrupting Cbl-b expression in tumor-reactive $\mathrm{T}$ cells may provide a unique strategy for increasing autocrine IL-2 production for promoting proliferative responses and survival following target recognition in the absence of costimulation and may also reduce the threshold for $\mathrm{T}$ cell activation to allow low-avidity $\mathrm{T}$ cells to respond to tumor targets expressing limiting amounts of antigen.

$\mathrm{Cblb}^{-/-}$mice are resistant to outgrowth of transplantable and spontaneous tumors $(12,22)$. Tumor resistance has been attributed to the increased responsiveness of the small number of naive tumor-reactive $\mathrm{Cblb}^{-/-} \mathrm{CD}^{+} \mathrm{T}$ cells present in the polyclonal repertoire, since adoptive transfer of naive $\mathrm{Cblb}^{-/-} \mathrm{CD}^{+} \mathrm{T}$ cells into tumor-bearing wild-type mice resulted in detectable therapeutic activity $(12,22)$. However, these studies are not directly applicable to human therapeutic settings, as current adoptive therapy protocols require expanding the small numbers of tumor-reactive T cells isolated from the host in vitro via multiple cycles of stimulation to produce adequate numbers of differentiated effector cells for infusion (23). In the disseminated Friend murine leukemia virusinduced (FMuLV-induced) FBL leukemia therapy mouse model (24), adoptive transfer of large numbers of in vitro expanded CD8 ${ }^{+}$ TCR transgenic T cells $\left(\mathrm{TCR}_{\mathrm{gag}}\right.$ cells) specific for an epitope derived 
A

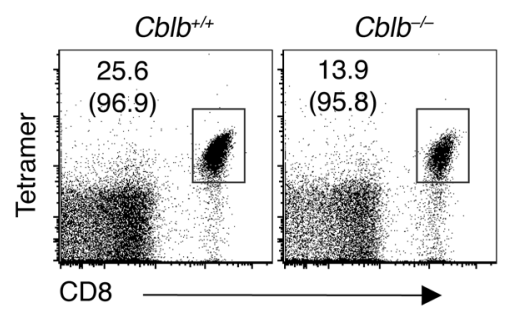

C

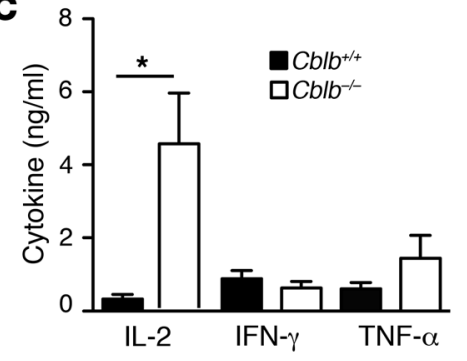

B

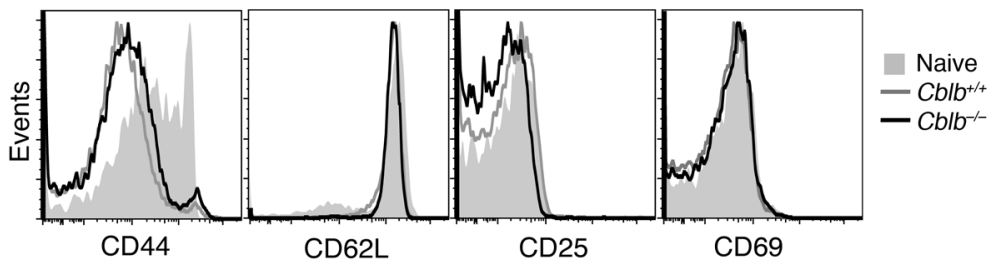

D

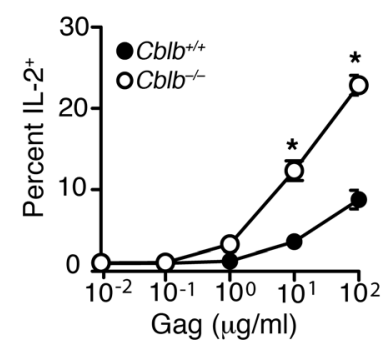

E
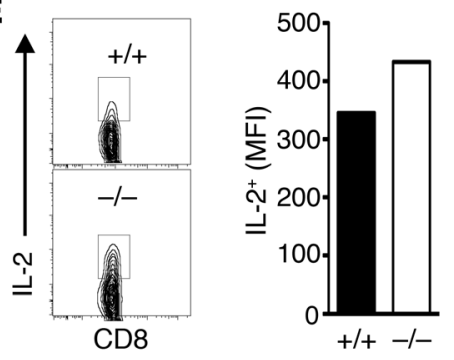

F

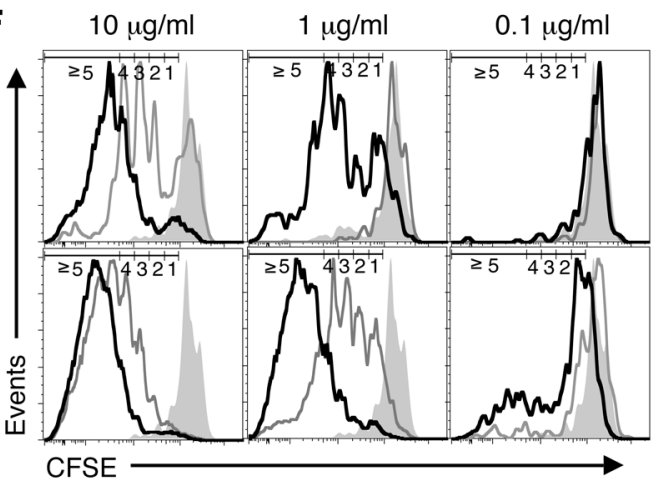

Figure 1

Cbl-b regulates IL-2 production and proliferation of naive TCR gag cells. (A) CD8 $\alpha$ and $\mathrm{H}-2 \mathrm{D}^{\mathrm{b}} / \mathrm{gag}$ tetramer staining of splenocytes isolated from naive $\mathrm{TCR}_{\mathrm{gag}} \mathrm{Cb} / \mathrm{b}^{+/+}$and $\mathrm{TCR}_{\mathrm{gag}} \mathrm{Cb} / \mathrm{b}^{-/-}$mice. The numbers in the plots indicate the percentages of CD8 ${ }^{+}$tetramer $^{+}$cells per spleen (top) and the percentages of CD8 ${ }^{+} \mathrm{T}$ cells in the spleen that bind tetramer (bottom). (B) Naive CD8 $8^{+}$tetramer $\mathrm{Cb}^{+} \mathrm{b}^{+/+}$and $\mathrm{Cb} / \mathrm{b}^{-/-}$cells were analyzed for CD44, CD62L, CD25, and CD69 expression using flow cytometry. (C) $\mathrm{TCR}_{\text {gag }} \mathrm{Cb} / \mathrm{b}^{+/+}$and $\mathrm{TCR}_{\mathrm{gag}} \mathrm{Cb} / \mathrm{b}^{-/-}$cells were stimulated with peptide-pulsed splenocytes $(5 \mu \mathrm{g} / \mathrm{ml})$, and cytokine production was assessed after 24 hours by a cytobead array. ${ }^{*} P<0.05\left(t\right.$ test). (D) $\mathrm{CD}^{+} \mathrm{TCR}_{\mathrm{gag}} \mathrm{Cb} / b^{+/+}$ and $\mathrm{TCR}_{\text {gag }} \mathrm{Cb} / \mathrm{b}^{-/-}$mice were stimulated as in $\mathbf{C}$, and the percentage of IL-2-secreting transgenic cells was determined by intracellular cytokine staining after 5 hours. ${ }^{*} P<0.005$ ( $t$ test). (E) MFI was quantified by gating on the IL-2-secreting population as shown in the representative FACS plot. (F) CFSE-labeled TCR $\mathrm{Tag}_{\mathrm{C}} \mathrm{Cb} / b^{+/+}$(gray line) and $\mathrm{TCR}_{\text {gag }} \mathrm{Cb} / b^{-/-}$(black line) CD8 cells were incubated with irradiated, congenic (Thy1.1 $\left.1^{+}\right)$ splenocytes pulsed with gag peptide. $\mathrm{r}-\mathrm{h}-\mathrm{IL}-2(25 \mathrm{U} / \mathrm{ml})$ was added to otherwise identical wells (bottom row). FACS plots were gated on Thy1.2 ${ }^{+}$ $\mathrm{CD}^{+} \mathrm{T}$ cells on day 3. Filled histograms indicate no antigen. Data is either representative of $2-3$ experiments $(\mathbf{A}, \mathbf{B}, \mathbf{E}$, and $\mathbf{F})$ or pooled from 3 independent experiments (C and $\mathbf{D})$.

from the gag protein of FMuLV that is expressed by FBL tumor cells is insufficient to mediate tumor regression, unless - similar to the requirement for efficacy in human clinical trials - injections of exogenous IL-2 are provided to promote persistence of transferred T cells $(14,25-27)$. The requirement for a prolonged $\mathrm{T}$ cell response in this model provides an ideal setting for testing the efficacy of strategies designed to improve $T$ cell activation, proliferation, and persistence.

We have used this mouse model of disseminated leukemia as well as in vitro cultured human effector $\mathrm{T}$ cell clones to examine whether ablating Cbl-b expression in in vitro expanded effector $\mathrm{T}$ cells might enhance the efficacy of adoptive immunotherapy. Naive and in vitro-derived effector $\mathrm{Cblb}^{+/+}$and $\mathrm{Cblb}^{-/-}$cells were evaluated to determine whether observed functional differ- ences were dependent on autocrine IL-2, paracrine IL-2, and/or CD28 signaling. The results demonstrate that ablating Cbl-benhanced mouse and human effector $T$ cell function via both IL-2-dependent and IL-2-independent pathways, restored some CD28-mediated functions in T cells and increased the efficacy of adoptive immunotherapy in a clinically relevant murine model of disseminated leukemia.

\section{Results}

Cbl-b regulates proliferation and $I L-2$ production in naive $T C R_{\text {gag }}$ cells. We generated $\mathrm{Cblb}^{-/-} \mathrm{TCR}_{\text {gag }}$ transgenic mice $\left(\mathrm{TCR}_{\mathrm{gag}} \mathrm{Cblb}^{--}\right.$mice), in which $\mathrm{CD}^{+} \mathrm{T}$ cells express an $\mathrm{H}-2 \mathrm{D}^{\mathrm{b}}$-restricted TCR specific to the gag epitope derived from FBL leukemia $(26,28)$. Although $\mathrm{Cblb}^{-/-}$mice have increased susceptibility to autoimmunity $(18,29)$, 
A

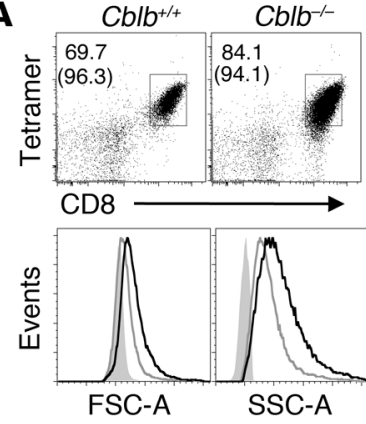

B

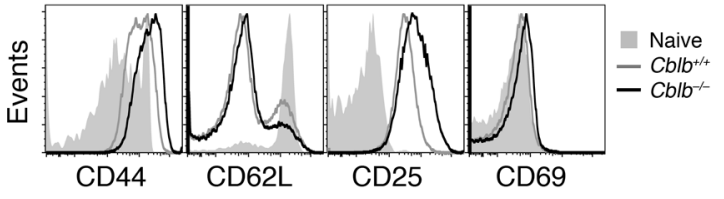

C
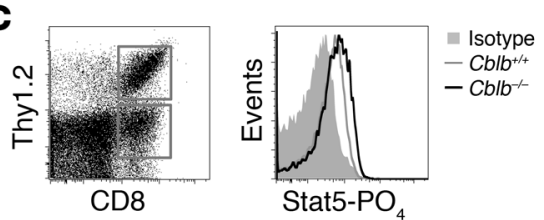

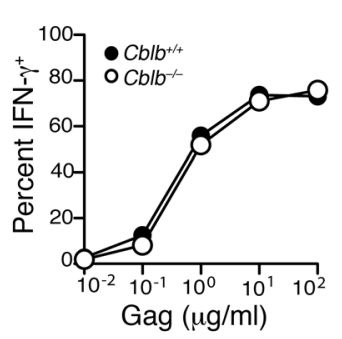

E

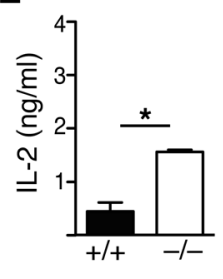

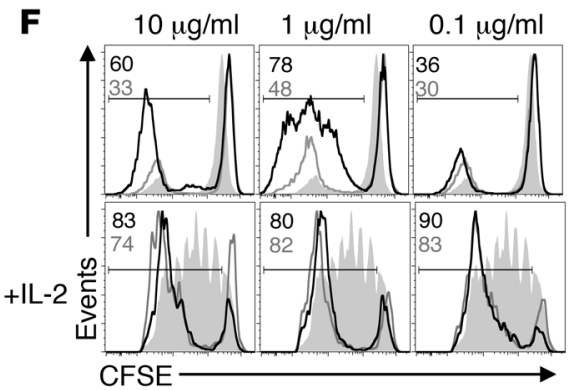

G

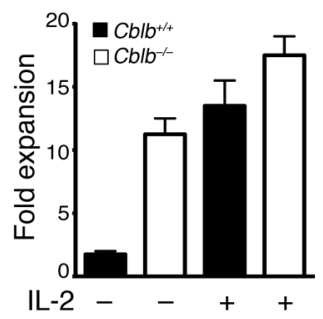

Figure 2

Proliferation of $\mathrm{TCR}_{\mathrm{gag}} \mathrm{Cb} / b^{-/-}$effector cells is independent of exogenous IL-2. TCR ${ }_{\mathrm{gag}} \mathrm{Cb} / \mathrm{b}^{+/+}$and $\mathrm{TCR}_{\mathrm{gag}} \mathrm{Cb}_{\mathrm{lb}} \mathrm{b}^{-/}$cells were cultured with antigen and r-h-lL-2 $(25 \mathrm{U} / \mathrm{ml})$ for 3 cycles of stimulation. (A) CD8 and tetramer staining of $\mathrm{Cb}_{1} \mathrm{~b}^{+/+}$and $\mathrm{Cb}^{-/ /-}$effector cells. The percentages of CD8 tetramer ${ }^{+}$cells in the culture (top) and the percentages of $\mathrm{CD}^{+}$cells that are also tetramer+ (bottom) are indicated. (B) Histogram overlays of $\mathrm{Cblb}^{-/-}$(black), $\mathrm{Cblb}^{+/+}$(gray) tetramer+, or naive CD8 cells (filled). Tetramer+ $\mathrm{Cblb}^{-/}$and $\mathrm{Cb}_{\mathrm{l}} \mathrm{b}^{+/+}$effectors cells were stained for various antigens and analyzed by FACS. (C) Thy $1.1^{+} \mathrm{TCR}_{\mathrm{gag}} \mathrm{Cb} / \mathrm{b}^{+/+}$cells were cultured with Thy $1.2^{+} \mathrm{TCR}_{\mathrm{gag}} \mathrm{Cb} / b^{-/-}$cells and antigen, stained for CD8 and congenic markers as shown, and analyzed for Stat5 phosphorylation after 24 hours. (D) Effector cells were stimulated with antigen and stained for intracellular IL-2 and IFN- $\gamma$. Data is gated on CD8 ${ }^{+}$Thy $1.2^{+}$cells. (E) IL-2 production was assessed 24 hours after activation with antigen using a cytometric bead array. ${ }^{*} P<0.05$ ( $t$ test). (F) CFSE-labeled effector $\mathrm{Cb}^{-b^{+/+}}$(gray line) and $\mathrm{Cblb}^{-/-}$(black line) Thy $1.2^{+}$cells were incubated with peptidepulsed, irradiated Thy $1.1^{+}$syngeneic splenocytes with or without r-h-IL-2 $(25 \mathrm{U} / \mathrm{ml})$. CFSE dilution was measured on day 4 . The numbers in the plots indicate the percentages of proliferating transgenic cells for $\mathrm{Cblb}^{+/+}$or $\mathrm{Cblb}^{-/}$, respectively, as indicated by color. Filled histograms indicate no antigen controls. (G) The fold expansion of effector cells 5 days after stimulation with antigen with or without r-h-lL-2 $(25 \mathrm{U} / \mathrm{ml})$. Data is representative of $2-3$ experiments $(\mathbf{A}-\mathbf{C}$, and $\mathbf{F})$ or pooled from 3 independent experiments ( $\mathbf{D}$ and $\mathbf{E})$.

$\mathrm{TCR}_{\mathrm{gag}} \mathrm{Cblb}^{-/}$mice, which express a defined nonautoreactive TCR, did not exhibit symptoms of autoimmunity and remained healthy in our colony. Nonmanipulated $\mathrm{TCR}_{\mathrm{gag}} \mathrm{Cblb}^{+/+}$and $\mathrm{TCR}_{\mathrm{gag}} \mathrm{Cblb}^{-/-}$ mice had, based on binding an $\mathrm{H}-2 \mathrm{D}^{\mathrm{b}}$ tetramer with the gag peptide, similar absolute numbers of transgenic cells (average number of tetramer cells per spleen, $2.9 \times 10^{7}$ vs. $2.4 \times 10^{7}$, respectively). Transgenic $\mathrm{T}$ cells from $\mathrm{TCR}_{\mathrm{gag}} \mathrm{Cblb}^{+/+}$and $\mathrm{TCR}_{\mathrm{gag}} \mathrm{Cblb}^{-/-}$ mice also expressed comparable levels of TCR (Figure 1A). Tetra- mer cells from both $\mathrm{TCR}_{\mathrm{gag}} \mathrm{Cblb}^{+/+}$and $\mathrm{TCR}_{\mathrm{gag}} \mathrm{Cblb}^{-/}$mice were CD $44^{\mathrm{lo}}, \mathrm{CD} 62 \mathrm{~L}^{\mathrm{hi}}$, $\mathrm{CD} 25^{-}$, and $\mathrm{CD} 69^{-}$, indicating that Cbl-b deficiency did not modify the phenotype of naive $\mathrm{TCR}_{\mathrm{gag}}$ cells (Figure 1B). $\mathrm{TCR}_{\mathrm{gag}} \mathrm{Cblb}^{-/}$cells produced significantly more IL-2 compared with TCR $_{\text {gag }}$ cells but did not differ in production of IFN- $\gamma$ or TNF- $\alpha$ (Figure 1C). Higher levels of IL-2 were due to both a significantly higher percentage of $\mathrm{TCR}_{\mathrm{gag}} \mathrm{Cblb}-/$ cells secreting IL-2 compared with $\mathrm{TCR}_{\mathrm{gag}} \mathrm{Cblb}^{+/}$cells (Figure 1D) as well as more IL-2 production on a per cell basis, as reflected by the MFI of IL-2 staining (Figure 1E). To evaluate whether Cbl-b regulates the threshold for naive $\mathrm{CD}^{+} \mathrm{T}$ cell proliferation, we incubated CFSE-labeled $\mathrm{TCR}_{\mathrm{gag}} \mathrm{Cblb}^{+/+}$ and $\mathrm{TCR}_{\mathrm{gag}} \mathrm{Cblb}^{-/-}$cells with splenocytes pulsed with titrating concentrations of peptide. $\mathrm{TCR}_{\mathrm{gag}} \mathrm{Cblb}-/$ cells proliferated in response to 10 -fold lower concentrations of peptide compared with $\mathrm{TCR}_{\mathrm{gag}} \mathrm{Cblb}^{+/+}$ cells (Figure 1F). In identical cell cultures supplemented with recombinant human IL-2 (r-h-IL-2) (25 U/ml), TCR gag $\mathrm{Cblb}^{-/-}$ cells still exhibited greater proliferation at all concentrations of peptide tested compared with $\mathrm{TCR}_{\mathrm{gag}} \mathrm{Cblb}^{++}$cells (Figure $1 \mathrm{~F}$, bottom row). The increased proliferation of $\mathrm{TCR}_{\mathrm{gag}} \mathrm{Cblb}^{-/-}$cells reflected both a higher proportion of cells entering cell cycle as well as a greater number of cell divisions. Although the observed greater IL-2 production likely contributed to the enhanced division, the failure of excess exogenous IL-2 to restore proliferative responses of $\mathrm{Cblb}^{+/+}$cells to the level of $\mathrm{Cblb}^{-/-}$cells suggests that IL-2-independent mechanisms may also contribute to the increased proliferative response in the absence of Cbl-b.

Cbl-b regulates $C D 8$ helper-dependent proliferation and IL-2 production in effector cells. Adoptive immunotherapy of cancer patients requires repeated in vitro expansion of antigen-specific $\mathrm{T}$ cells, which generally are derived from the nontolerized, naive repertoire and have been induced to differentiate to effector $\mathrm{CD} 8^{+}$ $T$ cells during in vitro manipulation $(2,3)$. Therefore, to model human adoptive immunotherapy protocols, we stimulated naive $\mathrm{TCR}_{\mathrm{gag}} \mathrm{Cblb}^{+/+}$and $\mathrm{TCR}_{\mathrm{gag}} \mathrm{Cblb}^{-/-}$cells in vitro with antigen in the presence of IL-2 and expanded the cells with 3 cycles of stimulation (denoted in vitroderived effector cells). Gating on tetramer cells on day 5 after the third cycle of in vitro expansion revealed that the absence of Cbl-b did not influence $\mathrm{CD} 8$ or TCR expression, although $\mathrm{TCR}_{\mathrm{gag}} \mathrm{Cblb}^{-/-}$ effectors were larger and more granular than wild-type cells (Figure $2 \mathrm{~A}$ ). Both $\mathrm{TCR}_{\mathrm{gag}} \mathrm{Cblb}^{+/+}$and $\mathrm{TCR}_{\mathrm{gag}} \mathrm{Cblb}^{-/-}$cells expressed cell 
A

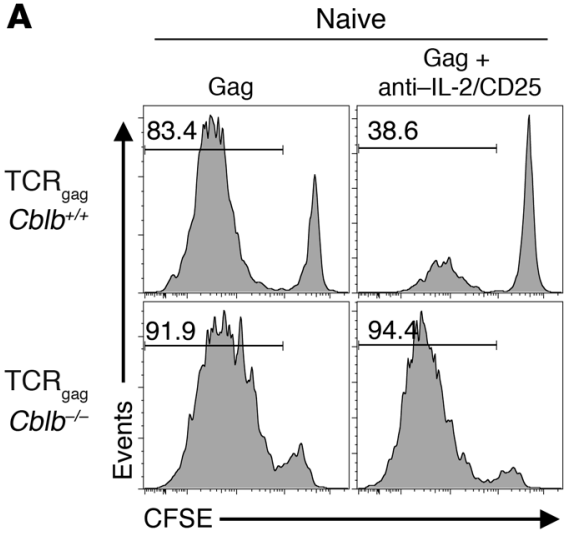

B

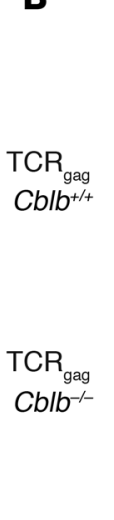

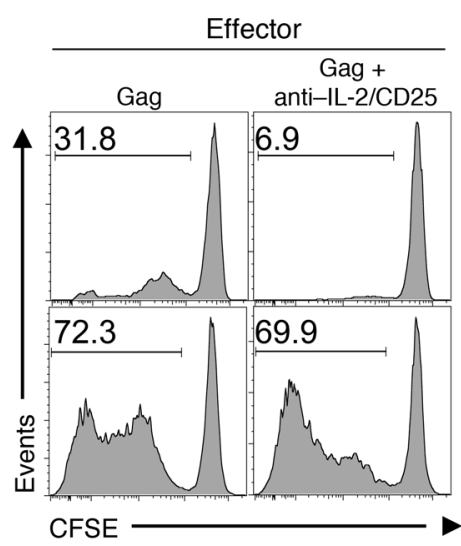

C

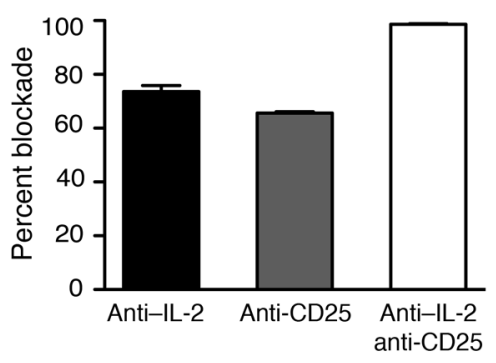

D

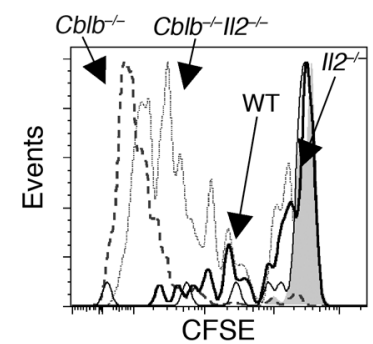

E

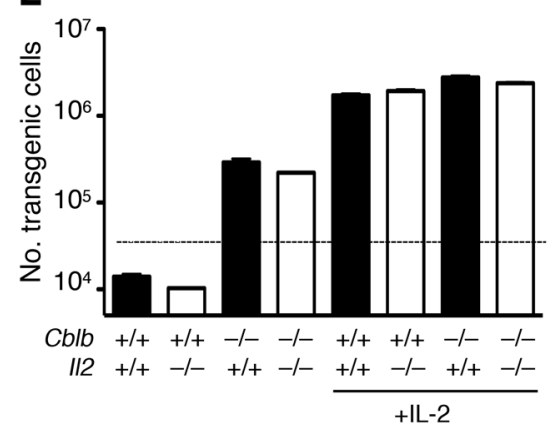

F
Effector

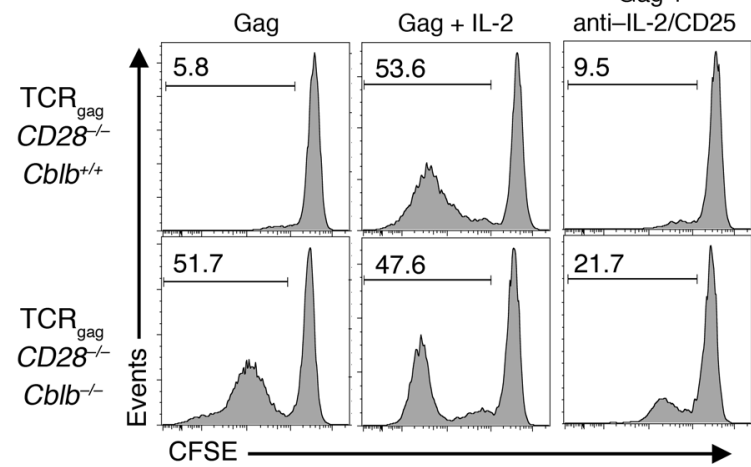

Figure 3

Cbl-b regulates IL-2-independent proliferation of both naive and effector T cells. (A) CFSE-labeled naive and (B) in vitro-derived effector Thy $1.2^{+}$ $\mathrm{TCR}_{\mathrm{gag}} \mathrm{Cb} / \mathrm{b}^{+/+}$and $\mathrm{TCR}_{\mathrm{gag}} \mathrm{Cb} / \mathrm{b}^{-/-}$cells were incubated with irradiated Thy $1.1^{+}$syngeneic splenocytes pulsed with $5 \mu \mathrm{g} / \mathrm{ml}$ of gag peptide, with and without anti-mouse CD25 $(20 \mu \mathrm{g} / \mathrm{ml})$ and anti-mouse IL-2 $(20 \mu \mathrm{g} / \mathrm{ml})$. After 4 days, CFSE dilution of Thy $1.2^{+}$CD $8^{+}$cells was determined by FACS. The numbers in each box indicate the percentage of proliferating transgenic cells. (C) CFSE-labeled CTLL-2 cells were incubated with r-mlL-2 (20 ng/ml) with or without anti-mouse CD25 $(20 \mu \mathrm{g} / \mathrm{ml})$, anti-mouse IL-2 $(20 \mu \mathrm{g} / \mathrm{ml})$, or a combination of these antibodies. After 4 days, proliferation was measured by CFSE dilution by FACS. Percentage blockade was calculated by dividing the percentage of CTLL-2 cell proliferation in the presence of antibody(s) by the percentage of CTLL-2 cell proliferation in the absence of antibody. (D) Proliferation of CFSE-labeled in vitro-derived effector $\mathrm{TCR}_{\text {gag }} \mathrm{Cb} / b^{+/+}, \mathrm{TCR}_{\text {gag }} / 2^{-/-}, \mathrm{TCR}_{\text {gag }} \mathrm{Cb} / b^{-/-}$, and $\mathrm{TCR}_{\text {gag }} \mathrm{Cb} / b^{-1-l / 2^{-/-}}$cells was determined 5 days after activation with antigen.

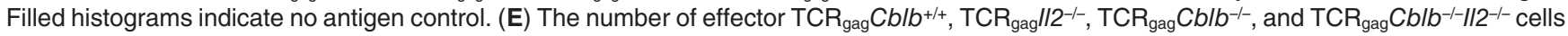
7 days after stimulation with antigen with or without r-h-lL-2 $(20 \mathrm{U} / \mathrm{ml})$. The dashed line indicates the number of effector cells that were plated at time 0. (F) In vitro-derived effector CFSE-labeled Thy1.2+TCR ${ }_{\text {gag }} C D 28^{-/-}$and $T C R_{\text {gag }} C D 28^{-/-} \mathrm{Cb} / b^{-/-}$cells were incubated with irradiated Thy $1.1^{+}$ syngeneic splenocytes pulsed with $5 \mu \mathrm{g} / \mathrm{ml}$ of gag peptide, with or without anti-mouse CD25 (20 $\mu \mathrm{g} / \mathrm{ml})$ and anti-mouse IL-2 (20 $\mu \mathrm{g} / \mathrm{ml})$. After 4 days, CFSE-dilution of Thy $1.2^{+}$CD8 ${ }^{+}$cells was analyzed. The numbers in each box indicate the percentage of proliferating transgenic cells.

surface markers predominantly consistent with an effector phenotype (CD44 ${ }^{\text {hi }}, \mathrm{CD}^{2} \mathrm{~L}^{\mathrm{lo}}$ ) (Figure $\left.2 \mathrm{~B}\right)$, but $\mathrm{TCR}_{\mathrm{gag}} \mathrm{Cblb}^{-/-}$effector cells expressed higher levels of CD44, CD25, and CD69. The higher expression of CD25 could be attributable to enhanced TCR signaling and/or more persistent activation from autocrine IL-2 usage by $\mathrm{TCR}_{\mathrm{gag}} \mathrm{Cblb}^{-/-} \mathrm{T}$ cells. To examine whether the absence of Cbl-b resulted in enhanced IL-2 signaling, $\mathrm{TCR}_{\mathrm{gag}} \mathrm{Cblb}^{+/+}$and $\mathrm{TCR}_{\mathrm{gag}} \mathrm{Cblb}^{-/-}$ effector cells were activated with antigen in the same wells, so that the cells would be exposed to a similar concentration of IL-2. After 1 day, effector cells were stained with antibodies to CD8 and Thy1.2 (a congenic marker that distinguished wild-type and $\mathrm{Cblb}^{-/-}$cells) and to phosphorylated-Stat5, which is downstream of the IL-2 receptor signal. $\mathrm{TCR}_{\mathrm{gag}} \mathrm{Cblb}^{-/}$cells exhibited higher expression of phosphorylated-Stat5, suggesting the higher CD25 expression in $\mathrm{Cblb}^{-/-}$effector cells is associated with augmented
IL-2R signaling (Figure 2C). The higher IL-2R $\alpha$ (CD25) expression on $\mathrm{Cblb}^{-1-}$ effector cells most likely reflects consequences of Cbl-bmediated regulation of TCR-dependent activation, since IL-2 signaling does not appear to be directly regulated by Cbl-b (30), but CD25 as well as CD69 are induced in part by signals from the TCR activating NF-кB $(31,32)$.

To determine whether Cbl-b regulates effector $\mathrm{T}$ cell function, we stimulated $\mathrm{TCR}_{\mathrm{gag}} \mathrm{Cblb}^{+/+}$and $\mathrm{TCR}_{\mathrm{gag}} \mathrm{Cblb}^{-/-}$effector cells with titrating doses of antigen and compared cytokine production and expression of cytolytic molecules. The percentage of $\mathrm{TCR}_{\mathrm{gag}} \mathrm{Cblb}^{-/-}$ effector cells that produced IL-2 was consistently slightly higher compared with that of $\mathrm{TCR}_{\mathrm{gag}} \mathrm{Cblb}^{+/+}$effector cells (Figure 2D), resulting in a small, but significant (3-fold) increase in the amount of IL-2 detected in the supernatant (Figure 2E). In contrast, we did not detect differences in IFN- $\gamma$ production, indicating avidity was 
A

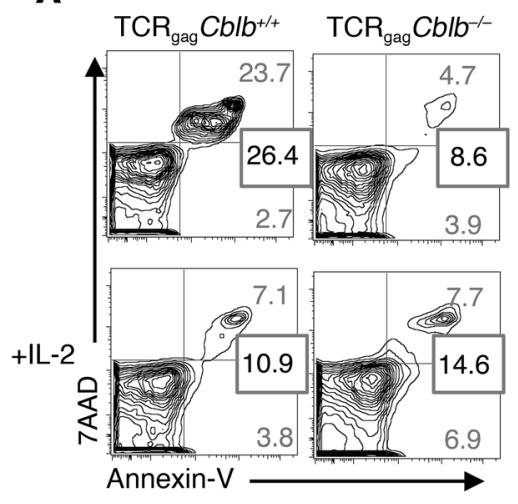

B

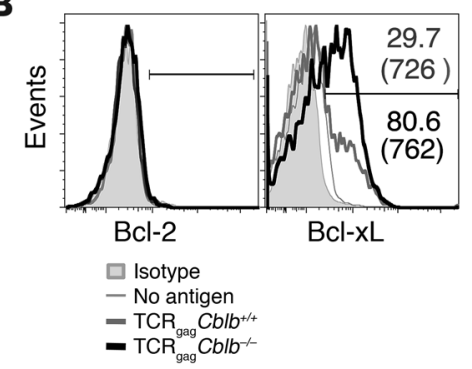

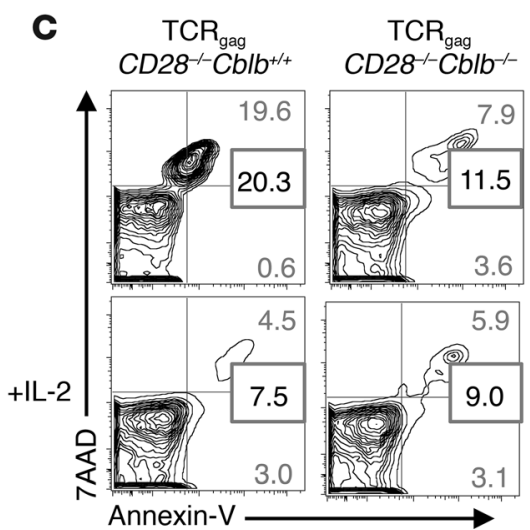

D

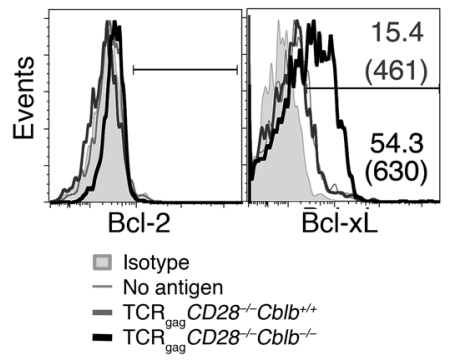

\section{Figure 4}

Ablating Cbl-b expression in both $\mathrm{CD}^{-} 8^{-}$and $\mathrm{CD}^{-} 8^{+}$ cells promotes $\mathrm{Bcl}-\mathrm{xL}$ expression and cell survival. (A and C) In vitro-derived effector cells were activated with antigen, with or without $\mathrm{r}-\mathrm{h}-\mathrm{IL}-2(25 \mathrm{U} / \mathrm{ml})$. After 4 days, the percentage of $\mathrm{CD}^{+}$transgenic cells stained for $7 A A D$ and/or Annexin- $V$ was determined by FACS analysis. The numbers in the top right quadrant indicate the percentage of transgenic T cells that are both Annexin- $\mathrm{V}^{+}$and $7 A \mathrm{AD}^{+}$. The numbers in the bottom right quadrant indicate the percentage of transgenic cells that are Annexin- $\mathrm{V}^{+}$ and $7 A A D^{-}$. The outlined numbers indicate the total percentage of transgenic cells that are Annexin- $\mathrm{V}^{+}$. (B and D) In vitro-derived Thy $1.2+{ }^{+} \mathrm{TCR}_{\text {gag }}$ effector cells of the indicated genotype were stimulated with peptide-pulsed Thy $1.1^{+}$splenocytes $(5 \mu \mathrm{g} / \mathrm{ml})$. After 4 days, $C D 8^{+}$Thy $1.2^{+}$were analyzed for intracellular expression of $\mathrm{Bcl}-2$ and $\mathrm{Bcl}-\mathrm{xL}$ using flow cytometry. The numbers in the plot indicate the percentage of transgenic cells that are positive for $\mathrm{BCl}-\mathrm{xL}$. Gray numbers correspond to (B) $\mathrm{TCR}_{\text {gag }} \mathrm{Cb} / \mathrm{b}^{+/+}$and (D) $\mathrm{TCR}_{\mathrm{gag}} \mathrm{Cb} \mathrm{b}^{+/+} \mathrm{CD} 28^{-/-}$cells, and black numbers correspond to (B) $\mathrm{TCR}_{\text {gag }} \mathrm{Cb} / b^{-/-}$and (D) $\mathrm{TCR}_{\text {gag }} \mathrm{Cb}^{-/-}$ $\mathrm{CD}_{28^{-/-}}$cells. The numbers in the parentheses indicate the MFI of the $\mathrm{Bcl}-\mathrm{xL}^{+}$population. Data represent 3 independent experiments. not changed (Figure 2D). The expression of granzyme B, perforin, and $\mathrm{CD} 107 \mathrm{a} / \mathrm{b}$ between $\mathrm{TCR}_{\mathrm{gag}} \mathrm{Cblb}^{+/+}$and $\mathrm{TCR}_{\mathrm{gag}} \mathrm{Cblb}^{-/-}$cells was also similar, suggesting that Cbl-b does not play a role in regulating cytolytic function of effector T cells (data not shown). To determine whether Cbl-b regulates helper-independent proliferation of effector T cells, CFSE-labeled $\mathrm{TCR}_{\mathrm{gag}} \mathrm{Cblb}^{+/+}$and $\mathrm{TCR}_{\mathrm{gag}} \mathrm{Cblb}^{-/}$ effector cells were stimulated with antigen for 4 days in the presence or absence of exogenous IL-2. In the absence of exogenous IL-2, a higher percentage of $\mathrm{TCR}_{\mathrm{gag}} \mathrm{Cblb}^{-/}$effectors proliferated compared with $\mathrm{Cblb}^{+/}$effectors (Figure 2F), while addition of exogenous IL-2 minimized proliferative differences (Figure 2F, bottom row). The enhanced proliferation of $\mathrm{TCR}_{\mathrm{gag}} \mathrm{Cblb}^{-/}$effector cells also resulted in an increase in absolute numbers of cells, as the number of $\mathrm{TCR}_{\mathrm{gag}} \mathrm{Cblb}^{-/-}$cells expanded more than 20 fold, even in the absence of exogenous IL-2 (Figure 2G). Thus, $\mathrm{TCR}_{\mathrm{gag}} \mathrm{Cblb}^{-/-}$ effectors cells have similar cytolytic function but increased proliferation and expansion in vitro in the absence of exogenous IL-2, characteristics that might translate into improved in vivo survival and efficacy in adoptive immunotherapy.

Cbl-b deficiency bypasses the requirement for IL-2 signaling for effector $T$ cell proliferation. Previous studies have shown that naive T cells can proliferate via both IL-2-dependent and IL-2-independent mechanisms $(33,34)$. In contrast to naive T cells, in vitro expanded effector $\mathrm{T}$ cells fail to proliferate in the absence of exogenous cytokines, such as IL-2. Therefore, we addressed whether the loss of Cbl-b influenced T cell proliferation via IL-2-dependent and/ or IL-2-independent pathways. To determine whether autocrine IL-2 was required for the enhanced proliferation of $\mathrm{TCR}_{\mathrm{gag}} \mathrm{Cblb}^{-/-}$ cells, we blocked IL-2 signaling in vitro. CFSE-labeled naive or in vitro-derived effector $\mathrm{TCR}_{\mathrm{gag}} \mathrm{Cblb}^{-/-}$or $\mathrm{TCR}_{\mathrm{gag}} \mathrm{Cblb}^{+/+}$cells were incubated with a combination of mAbs to both neutralize IL-2 in solution and to block binding to CD25 during in vitro activation with antigen. Four days later, we analyzed CFSE dilution in the presence or absence of IL-2 blockade to quantify cell proliferation.
Consistent with previous studies $(35,36)$, IL-2 blockade inhibited some but not all antigen-induced proliferation of naive wild-type $\mathrm{TCR}_{\text {gag }}$ cells (Figure 3A). In contrast, IL-2 blockade did not affect the proliferation of naive $\mathrm{TCR}_{\mathrm{gag}} \mathrm{Cblb}^{-/-}$cells (Figure 3A) or cell survival, as we observed significant expansion of $\mathrm{Cblb}^{-/-}$effector cells (data not shown). IL-2 blockade completely suppressed the small amount of proliferation that was observed in wild-type in vitro-derived effector cells but did not inhibit the proliferation of effector $\mathrm{TCR}_{\mathrm{gag}} \mathrm{Cblb}^{-/-}$cells (Figure $3 \mathrm{~B}$ ). The results suggest that Cbl-b regulates not only IL-2 production and the resulting IL-2induced proliferation, but also regulates IL-2-independent $\mathrm{T}$ cell proliferation of both naive and effector T cells.

To determine whether the concentrations of the combined IL-2 blocking antibodies used in these studies were efficiently blocking physiological levels of IL-2 in these experiments, we cultured CFSElabeled CTLL-2 cells, an IL-2-responsive cell line $(37,38)$, with $2 \mathrm{ng} / \mathrm{ml}$ recombinant mouse IL-2 (r-mIL-2), and with either blocking antibody alone or with r-mIL-2 and a combination of both blocking antibodies. Three days later, CFSE dilution was measured to quantify CTLL-2 cell proliferation. The combination of both blocking antibodies completely suppressed CTLL-2 cell proliferation in response to $2 \mathrm{ng} / \mathrm{ml} \mathrm{r-mIL-2} \mathrm{(Figure} \mathrm{3C)} \mathrm{and} \mathrm{inhibited} \mathrm{over}$ $90 \%$ of CTLL- 2 cell proliferation in response to 1 log higher concentration of r-mIL-2 $(20 \mathrm{ng} / \mathrm{ml})$, which greatly exceeds the amount detected in activated $T$ cell supernatants (data not shown).

To confirm that $\mathrm{Cblb}^{-/-}$effector $\mathrm{T}$ cell proliferation could be fully independent of autocrine IL-2, we crossed our mice to knockout mice lacking the IL-2 gene $\left(\mathrm{TCR}_{\mathrm{gag}} \mathrm{Cblb}^{-/-} \mathrm{Il}^{-/-}\right.$mice and control $\mathrm{TCR}_{\mathrm{gag}} \mathrm{Il} 2^{-/-}$mice). As predicted, naive (CD44lo ${ }^{\mathrm{l}}$ CD62 $\mathrm{L}^{\mathrm{hi}}$, $\left.\mathrm{CD}^{+}, \mathrm{Val}^{+}\right) \mathrm{TCR}_{\mathrm{gag}} \mathrm{Cblb}^{+/+}, \mathrm{TCR}_{\mathrm{gag}} \mathrm{Cblb}^{-/-}, \mathrm{TCR}_{\mathrm{gag}} \mathrm{Cblb}^{+/+} \mathrm{Il}^{+/+}$, and $\mathrm{TCR}_{\text {gag }} \mathrm{Cblb}^{-/-} \mathrm{Il2^{-/- }}$ cells proliferated in response to antigen stimulation independent of exogenous IL-2 (data not shown). After 3 cycles of stimulation with antigen and exogenous IL-2 in vitro to generate effector cells, only $\mathrm{TCR}_{\mathrm{gag}} \mathrm{Cblb}^{-/-}$and $\mathrm{TCR}_{\mathrm{gag}} \mathrm{Cblb}^{-/-} \mathrm{Il2^{-/- }}$ 
A
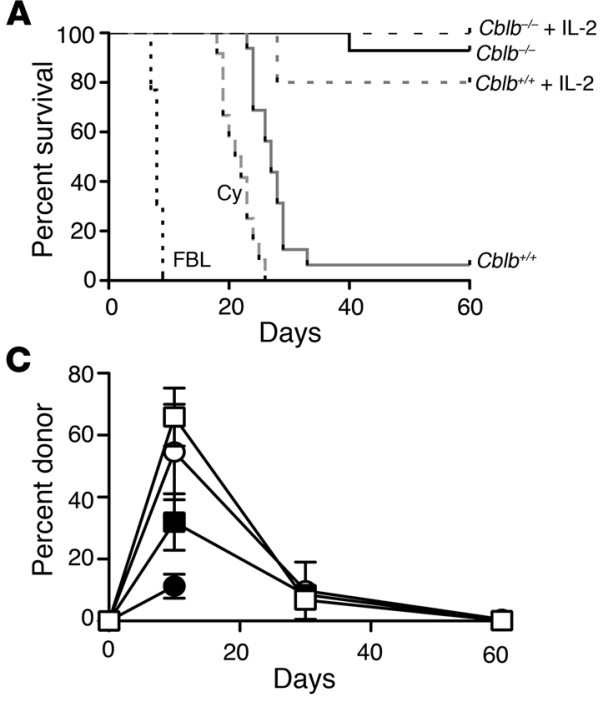

B

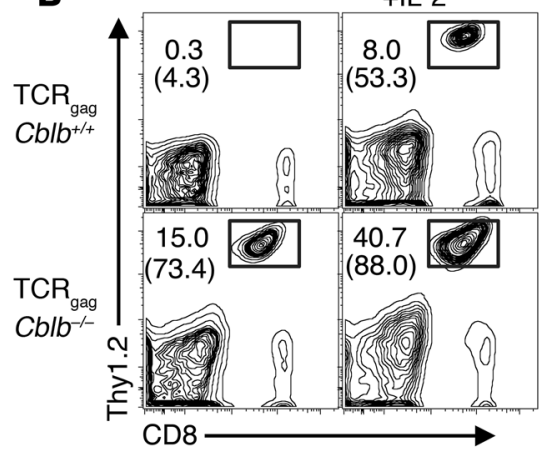

Figure 5

Abrogating $\mathrm{Cbl}-\mathrm{b}$ expression in tumor-reactive $\mathrm{TCR}_{\text {gag }}$ cells during adoptive immunotherapy of disseminated leukemia. (A) Thy1.1 B6 mice were injected with $5 \times 10^{6}$ live FBL. Five days later, mice received Cytoxan $\left(180 \mathrm{mg} / \mathrm{kg}\right.$ ), followed by injection of $1 \times 10^{5} \mathrm{Thy} 1.2^{+} \mathrm{TCR}_{\mathrm{gag}} \mathrm{Cb}_{\mathrm{b}} \mathrm{b}^{+/+}$or

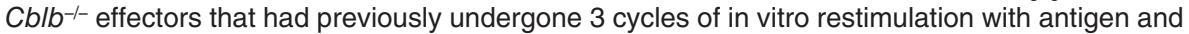
r-h-IL-2 (25 U/ml). Some recipients also received IL-2 (104 U/mouse for 10 days). Transfer of $\mathrm{TCR}_{\text {gag }} \mathrm{Cb} / \mathrm{b}^{-/-}$cells significantly improved survival in the absence of IL-2 administration compared with $\mathrm{TCR}_{\text {gag }}$ cells $(P<0.0001$, log-rank Mantel-Cox test). Data were pooled from 3 independent experiments ( $n=10-16$ mice/group). Cy, cyclophosphamide. (B) Representative FACS plots of donor Thy $1.2^{+} \mathrm{CD}^{+} \mathrm{T}$ cells in the blood 10 days after $\mathrm{T}$ cell transfer during therapy. The percentage of donor cells in the blood (top) and the percentage of donor Thy 1.2 cells of the CD8 cells (bottom) is indicated. (C) The percentage of donor T cells in the spleen was determined by FACS. TCR gag $\mathrm{Cb}^{-/ /}$cells (white symbols) expanded significantly better than wild-type $\mathrm{TCR}_{\text {gag }}$ cells (black symbols) in either the presence (squares) or absence (circles) of IL-2 injections at day $10(P<0.05$ and $P<0.005$, respectively, $t$ test $)$.

effector cells proliferated in response to antigen in the absence of exogenous IL-2 (Figure 3D). At day 5 , in response to stimula-

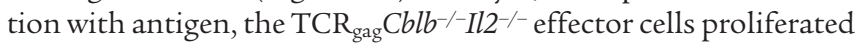
somewhat less than $\mathrm{TCR}_{\mathrm{gag}} \mathrm{Cblb}^{-/}$cells capable of producing autocrine IL-2 (Figure 3D), but by day 7, the numbers of TCR $\mathrm{gag}_{\mathrm{Cblb}}-/$ and $\mathrm{TCR}_{\mathrm{gag}} \mathrm{Cblb}^{-/-} \mathrm{Il} 2^{-/-}$effector cells that had expanded and survived were similar (Figure 3E). Addition of exogenous IL-2 and antigen resulted in significantly more, but essentially identical, expansion of $\mathrm{TCR}_{\mathrm{gag}} \mathrm{Cblb}^{+/+}, \mathrm{TCR}_{\mathrm{gag}} \mathrm{Cblb}^{-/,}, \mathrm{TCR}_{\mathrm{gag}} \mathrm{Cblb}^{+/+} \mathrm{Il}^{+/+}$and $\mathrm{TCR}_{\mathrm{gag}} \mathrm{Cblb}-/ \mathrm{Il}^{--}-$cells (Figure 3E). Thus, abrogating Cbl-b expression permits proliferation of effector $\mathrm{CD} 8^{+} \mathrm{T}$ cells in the absence of exogenous or autocrine IL-2.

CD28 costimulatory signals can enhance $T$ cell expansion via both IL-2-dependent and IL-2-independent mechanisms $(35,39)$. Previous studies have demonstrated that Cbl-b dampens CD28 signals in naive $\mathrm{T}$ cells and that $\mathrm{Cbl}-\mathrm{b}$ deficiency results in reduced requirements for $\mathrm{CD} 28$ signaling for naive $\mathrm{T}$ cell proliferation $(16,17,22)$. Therefore, we wanted to address whether Cbl-b deficiency reduces the requirement for CD28 signaling and/or IL-2 production for proliferation of effector T cells. CFSE-labeled in vitro-derived effector $\mathrm{TCR}_{\mathrm{gag}} \mathrm{CD} 28^{-/-} \mathrm{Cblb}^{+/+}$and $\mathrm{TCR}_{\mathrm{gag}} \mathrm{CD} 28^{-/-}$ $\mathrm{Cblb}^{-/}$cells were activated in vitro with antigen for 4 days in the presence or absence of IL-2 blocking antibodies. While both $\mathrm{TCR}_{\mathrm{gag}} \mathrm{CD} 28^{-/-} \mathrm{Cblb}^{+/+}$and $\mathrm{TCR}_{\mathrm{gag}} \mathrm{CD} 28^{-/-} \mathrm{Cblb}^{-/-}$effector cells proliferated in the presence of antigen and exogenous IL-2 (Figure 3F), which is $\mathrm{CD} 28$ responsive, both promote $\mathrm{T}$ cell survival. On day 4 after $\mathrm{T}$ cell activation, effector cells that had been stimulated with antigen in the absence of exogenous IL-2 were stained for intracellular Bcl-2 and Bcl-xL expression. Although Bcl-2 expression levels were not sufficient for detection in both $\mathrm{TCR}_{\mathrm{gag}} \mathrm{Cblb}^{+/+}$or $\mathrm{TCR}_{\mathrm{gag}} \mathrm{Cblb}^{-/-}$effector cells, $\mathrm{TCR}_{\mathrm{gag}} \mathrm{Cllb}^{-/-}$ effector cells did express higher levels of $\mathrm{Bcl}-\mathrm{xL}$ than wild-type cells (Figure 4B). Thus, increased expression of $\mathrm{Bcl}-\mathrm{xL}$ in $\mathrm{Cblb}^{-/}$effector cells likely contributes to the increased cell survival.

To assess whether Cbl-b deficiency bypassed CD28 signaling for enhanced survival, we performed similar experiments with $\mathrm{TCR}_{\mathrm{gag}} \mathrm{CD} 28^{-/-} \mathrm{Cblb} b^{+/+}$and $\mathrm{TCR}_{\mathrm{gag}} \mathrm{CD} 28^{-/-} \mathrm{Cblb}^{-/}$effector cells. $\mathrm{TCR}_{\mathrm{gag}} \mathrm{CD} 28^{-/-} \mathrm{Cblb}^{-/}$cells exhibited a lower percentage of Annexin- $\mathrm{V}^{+}$cells compared with $\mathrm{TCR}_{\mathrm{gag}} \mathrm{CD} 28^{-/-} \mathrm{Cblb^{+/+ }}$ cells, which was again associated with higher levels of $\mathrm{Bcl}-\mathrm{xL}$ expression (Figure 4, C and D). Addition of exogenous IL-2 decreased the percentage of $\mathrm{Cblb}^{+/+} \mathrm{CD} 28^{-/-}$and $\mathrm{Cblb}^{-/-} \mathrm{CD} 28^{+/+}$Annexin- $-\mathrm{V}^{+}$ effector cells. In the presence of exogenous IL-2, a slightly higher percentage of $\mathrm{CD} 28^{-/-} \mathrm{Cblb}^{-/-}$cells were Annexin- $\mathrm{V}^{+}$compared

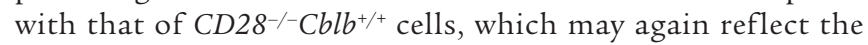
greater proliferation of $\mathrm{Cblb}^{-/-}$cells. Thus, ablating Cbl-b expression in either $\mathrm{CD}_{28} 8^{+}$or $\mathrm{CD} 28^{-}$effector cells enhances Bcl-xL expression and survival.

Ablating Cbl-b in tumor-reactive $C D 8^{+} T$ cells cures mice of disseminated lenkemia and bypasses the requirement for exogenous IL-2 administration. To best mimic human adoptive immunotherapy protocols, 

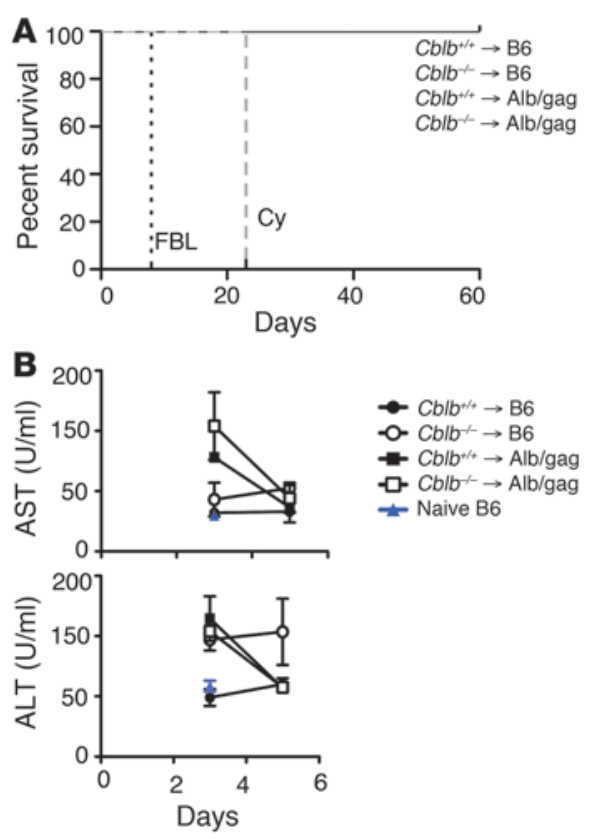

C
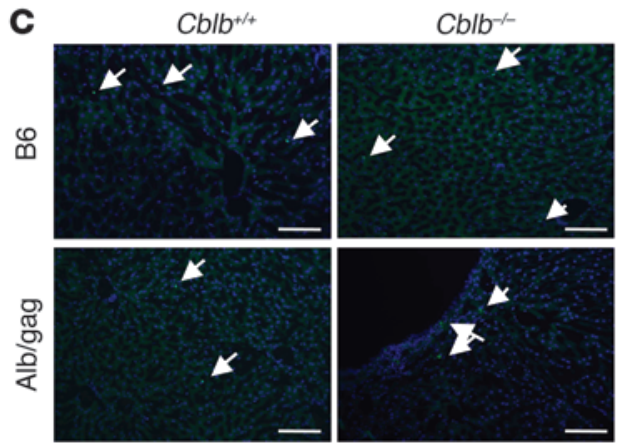

we investigated whether effector $\mathrm{CD}^{+} \mathrm{T}$ cells with abrogated Cbl-b expression would enhance therapeutic efficacy in a mouse therapy model of disseminated leukemia. B6 Thy1.1 mice were inoculated with a lethal dose of FBL leukemia (40), and 5 days later, when leukemia was disseminated, mice were treated with cyclophosphamide chemotherapy, followed in 6 hours with

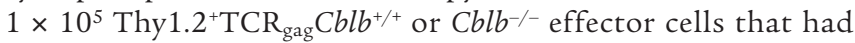
been expanded in vitro by 3 consecutive cycles of antigen stimulation in the presence of exogenous IL-2 $(25 \mathrm{U} / \mathrm{ml})$. A cohort of mice from each group also received low-dose intraperitoneal IL-2 $\left(10^{4} \mathrm{U} /\right.$ day $)$ for 10 days, which we have previously shown enhances therapeutic efficacy by promoting the survival of wildtype $\mathrm{TCR}_{\text {gag }}$ cells and is required for complete tumor eradication (40). In the absence of exogenous IL-2, T cell therapy prolonged survival in only 1 out of 16 recipients of $\mathrm{TCR}_{\mathrm{gag}} \mathrm{Cblb}^{+/+}$cells, whereas 13 out of 14 recipients of $\mathrm{TCR}_{\mathrm{gag}} \mathrm{Cblb}^{-/}$cells appeared healthy and disease free at day $60(P<0.0001$; Figure 5A). By contrast, $\mathrm{TCR}_{\mathrm{gag}} \mathrm{Cblb}^{+/+}$recipients or $\mathrm{TCR}_{\mathrm{gag}} \mathrm{Cblb}^{-/-}$recipients that also received IL-2 injections nearly uniformly achieved prolonged survival ( 9 out of 10 or 10 out of 10 , respectively). Control in vitro-activated non-antigen-specific $\mathrm{P} 14 \mathrm{Cblb}^{-/-}$did not extend survival or cure any mice of tumor (data not shown), indicating, as extensively previously demonstrated, that $\mathrm{T}$ cell specificity is required in this model (25).

\section{Figure 6}

Cbl-b deficiency does not enhance autoimmune toxicity during adoptive therapy of disseminated leukemia when the tumor antigen is also expressed as a self-antigen in the liver. (A) B6 and Alb/gag mice were injected with $5 \times 10^{6}$ live $\mathrm{FBL}$. On day 5 , mice received Cytoxan $(180 \mathrm{mg} / \mathrm{kg})$, followed by injection of $1 \times 10^{6}$ in vitro-derived effector $\mathrm{TCR}_{\text {gag }} \mathrm{Cb} \mathrm{b}^{+/+}$or $\mathrm{TCR}_{\text {gag }} \mathrm{Cb} / b^{-/-}$cells. Recipients received IL-2 injections ( $10^{4} \mathrm{U} /$ mouse for 10 days). (B) At the indicated times after $\mathrm{T}$ cell transfer, serum was harvested and expression of the liver enzymes aspartate aminotransferase (AST) and alanine aminotransferase (ALT) was measured (2-3 mice/group). (C) At day 7 after T cell transfer, the livers were harvested from 3-4 mice per group. Seven $\mu \mathrm{M}$ liver sections were stained with antibodies to CD8 and the nuclear stain DAPI and analyzed by fluorescent microscopy. Arrows indicate CD8 ${ }^{+}$cells. Scale bar: $200 \mu \mathrm{M}$.

To evaluate whether ablating Cbl-b regulated $\mathrm{T}$ cell expansion and persistence during adoptive immunotherapy, we measured the percentage of donor T cells (Thy $1.2^{+}$) in the blood and spleen at various time points after $\mathrm{T}$ cell transfer. Consistent with the enhanced therapeutic efficacy in the absence of exogenous IL-2 injections, $\mathrm{TCR}_{\mathrm{gag}} \mathrm{Cblb}^{-/-}$cells were detected at a 5-fold higher frequency than $\mathrm{TCR}_{\text {gag }} \mathrm{Cblb}^{+/+}$cells at 10 days after $\mathrm{T}$ cell transfer (Figure 5, B and C; $P<0.05$ ). Exogenous IL-2 injections promoted the expansion of both wild-type and $\mathrm{Cblb}^{-/-}$effectors during therapy (Figure 5, B and C). However, neither transferred effector cell population formed substantial numbers of long-term memory cells regardless of IL-2 administration, as reflected by the failure to detect persisting transferred cells at day 60 (Figure 5C). These results are consistent with clinical data, indicating that effector cells expanded in vitro with IL-2 become terminally differentiated and fail to generate memory $\mathrm{T}$ cells with a self-renewal capacity (2). Thus, ablating Cbl-b does not appear to enhance the ability of in vitro-derived effector $T$ cells to form long-term memory but rather acts to enhance the early proliferation and sustain the initial survival of $\mathrm{T}$ cells during the period required for tumor eradication.

We also evaluated whether abrogating Cbl-b in naive or minimally expanded T cells also imparts the enhanced efficacy of adoptive immunotherapy of disseminated leukemia, as improved techniques are being developed that may allow the generation of cells for therapy with the requirement for less in vitro expansion. Therefore, we transferred titrating doses of naive or minimally expanded (stimulated 1 cycle in vitro) $\mathrm{TCR}_{\mathrm{gag}} \mathrm{Cblb}^{+/+}$and $\mathrm{TCR}_{\mathrm{gag}} \mathrm{Cblb}^{-/-}$cells into tumor-bearing mice. At the lowest $\mathrm{T}$ cell dose tested $\left(1 \times 10^{4}\right.$ $\mathrm{T}$ cells), only naive $\mathrm{Cblb}^{-1-} \mathrm{T}$ cells exhibited any therapeutic activity, but this was modest, with only $33 \%$ surviving in the absence of exogenous IL-2 and with $67 \%$ and $33 \%$ surviving in the presence of exogenous IL-2 following treatment with naive $\mathrm{Cblb}^{-/-}$and $\mathrm{Cblb}^{-/-}$ $T$ cells expanded by a single in vitro cycle, respectively (Supplemental Figure 1; supplemental material available online with this article; doi:10.1172/JCI41991DS1). At a dose of $1 \times 10^{5} \mathrm{~T}$ cells, Cblb Cl- $^{-1}$ $\mathrm{T}$ cells stimulated for a single cycle were equally as effective as naive $\mathrm{Cblb}^{-/-} \mathrm{T}$ cells, similar to what we observed with effector cells generated with 3 cycles of stimulation (Figure 5A), and again were therapeutically effective without requiring IL-2. By contrast, naive $\mathrm{Cblb}^{+++} \mathrm{T}$ cells were not effective at any tested dose in the absence of exogenous IL-2 and only exhibited any therapeutic activity at a dose of $1 \times 10^{5} \mathrm{~T}$ cells. Thus, targeting Cbl-b expression in $\mathrm{CD}^{+}$ $\mathrm{T}$ cells that have undergone even minimal expansion in vitro still provides therapeutic benefit. 

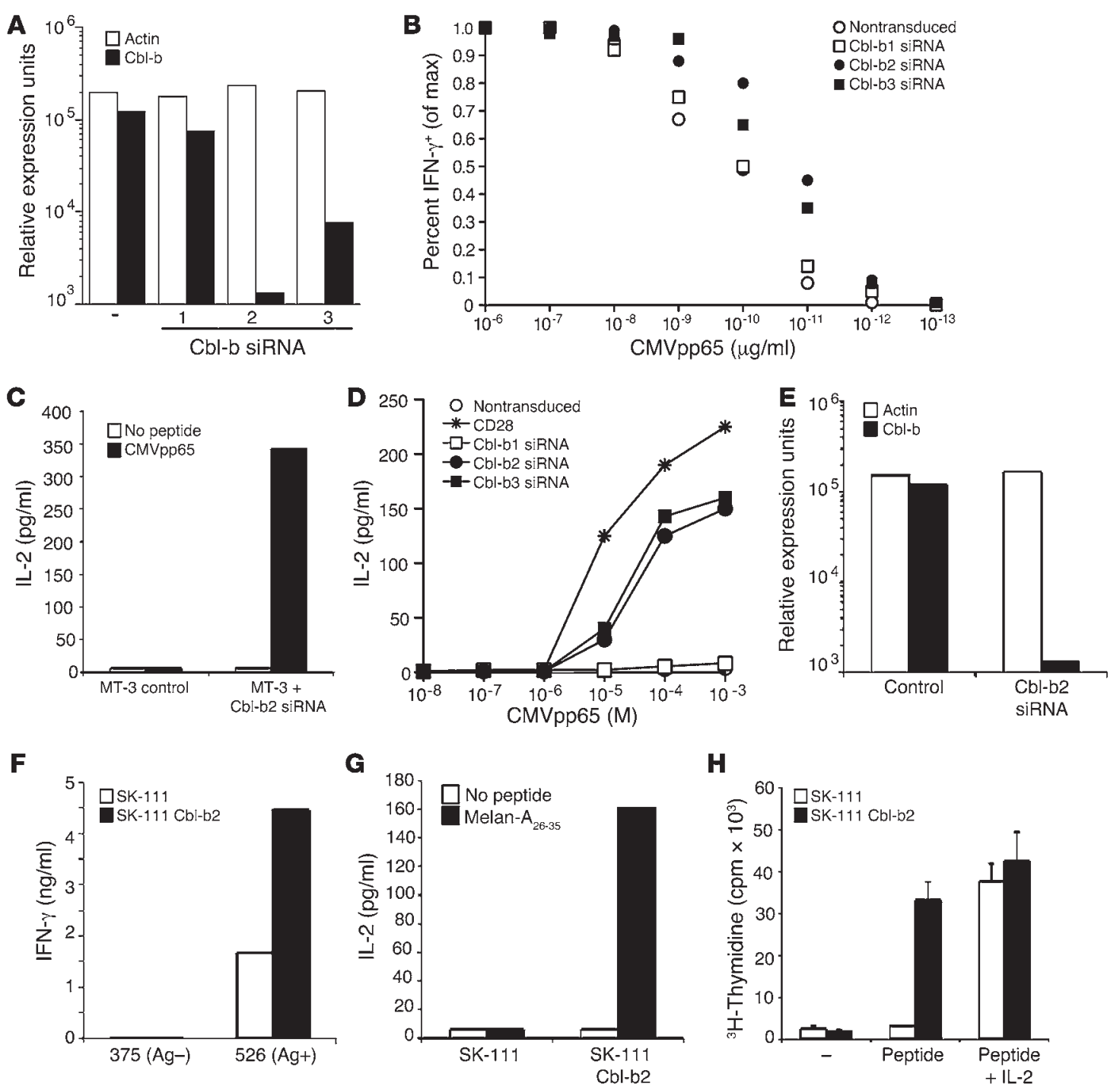

\section{Figure 7}

Targeting Cbl-b expression by siRNA in human effector CD8+CD28- $\mathrm{T}$ cell clones restores T cell function. (A) Human CD8 ${ }^{+}$CD28- CMV-specific effector T cell clones (MT-3) were transduced with 1 out of 3 Cbl-b-specific siRNAs (Cbl-b1, Cbl-b2, or Cbl-b3), and their efficiency in reducing Cbl-b protein levels relative to Actin was measured by Western blot. (B) Parental and siRNA-transduced MT-3 cell clones were incubated with CMVpp65 peptide-pulsed APCs, and the percentage of IFN- $\gamma$-positive clones was determined by intracellular cytokine staining and normalized to the percentage of the maximum response. (C) MT-3 clones transduced with Cbl-b2 siRNA, and control clones (vector only) were incubated with T2 cells (HLA-A2+) with or without CMVpp65. After 24 hours, IL-2 secretion was quantified by a cytobead array. (D) IL-2 secretion by parental and transduced MT-3 clones after antigen stimulation. As a positive control, MT-3 clones were also transduced with CD28 as described previously (21). (E) The efficiency of Cbl-b2 siRNA in knocking down Cbl-b relative to Actin in human CD8+CD28- MelanA-specific clones (SK-111) was determined by Western blot. (F) Parental or Cbl-b2 siRNA-transduced SK-111 cells were incubated with antigen-negative (Ag-) HLA-A2+

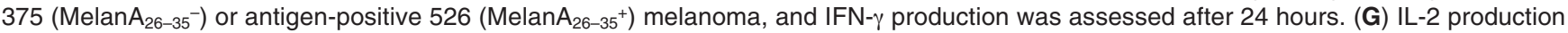
by parental and Cbl-b2 siRNA-transduced SK-111 T cells was measured 24 hours after stimulation with T2 cells with or without MelanA $\mathrm{A}_{26-35}$ peptide. (H) The proliferation of Cbl-b2 siRNA-transduced and parental SK-111 T cells in response to antigen with or without r-h-IL-2 (50 U/ml) was measured by ${ }^{3} \mathrm{H}$-thymidine incorporation.

Adoptive immunotherapy with $\mathrm{TCR}_{\mathrm{gag}} \mathrm{Cblb}^{-/-}$cells does not result in autoimmune injury. Previous studies in our laboratory demonstrated that adoptive therapy with $\mathrm{TCR}_{\mathrm{gag}}$ cells in mice that express the gag tumor antigen also as a self antigen selectively in the liver does not result in detectable autoimmune injury (25). Since Cbl-b deficiency lowers the threshold for $\mathrm{T}$ cell activation and renders cells resistant to regulatory mechanisms such as TGF- $\beta$-mediated suppression and anergy induction $(12,22)$, we evaluated whether using $\mathrm{T}$ cells with abrogated Cbl-b expression in adoptive therapy influences autoimmune toxicity by transferring $\mathrm{TCR}_{\mathrm{gag}} \mathrm{Cblb}^{-/-}$cells in a therapeutic setting in which these cells recognize an antigen not only expressed at high levels by the tumor but also at lower levels in normal tissues, similar to many human tumor antigens. Control B6 mice and mice that express the gag transgene selectively in the liver (Alb/gag mice) were used as recipients for therapy of FBL leukemia. Transfer of $1 \times 10^{6} \mathrm{TCR}_{\mathrm{gag}}$ or $\mathrm{TCR}_{\mathrm{gag}} \mathrm{Cblb}^{-/-}$in 
vitro-derived effector T cells, in combination with exogenous IL-2, cured Alb/gag mice of disseminated FBL (Figure 6A) but did not result in detectable autoimmunity, with all recipients appearing healthy through day 60. Neither Alb/gag mice nor B6 mice exhibited persistent elevations of the liver enzymes after $\mathrm{T}$ cell transfer, and there was no evidence of increased $\mathrm{CD}^{+} \mathrm{T}$ cell infiltration into the liver of Alb/Gag mice (Figure 6, B and C).

$C D 28^{-} C D 8^{+}$buman $T$ cell clones transduced with siRNA that targets Cbl-b restore IL-2 production and autocrine-mediated proliferation and lower the threshold for activation. Loss of CD28 expression commonly occurs in vivo during differentiation of human antigen-specific $\mathrm{CD}^{+} \mathrm{T}$ cells to effector/memory cells, resulting in an inability to both produce IL-2 and to support autocrine IL-2-mediated proliferation (41). CD28 is also generally not detected on effector T cells used for adoptive immunotherapy, as a result of differentiation during the repetitive in vitro stimulations with antigen necessary for $\mathrm{T}$ cell expansion. We have previously shown that restoration of CD28 expression in this population restores IL-2 production, indicating that CD28- effector cells retain the intracellular signaling pathways required to produce IL-2 (21). Based on these observations, as well as the enhanced function of murine $\mathrm{Cblb}^{-/-}$effector cells, we investigated whether targeting Cbl-b expression has functional consequences in human effector CD8 cells. We transduced the human $\mathrm{CD}^{+} \mathrm{CD} 28^{-}$cytomegalovirus-specific (CMVpp65-specific) effector T cell clone (MT-3) with retroviral vectors expressing Cbl-b-specific siRNAs designed to specifically target 3 different sequences in Cblb mRNA (the 3 different siRNA sequences are referred to as Cbl-b1, Cbl-b2, and Cbl-b3, as described in the Methods). The siRNA Cbl-b2 reduced Cbl-b protein expression by approximately 100 fold, while the siRNA Cbl-b3 reduced protein levels by approximately 10 fold (Figure 7A). To determine whether decreasing Cbl-b expression influenced functional avidity of CMV-specific clones, we cultured parental (unmodified) and Cbl-b siRNA-transduced MT-3 cells with APCs pulsed with decreasing concentrations of CMVpp65 $495-503$ peptide, and IFN- $\gamma$ secretion was measured by intracellular cytokine staining. Cbl-b2 siRNA-transduced MT-3 cells responded to a log lower concentration of peptide compared with nontransduced cells, indicating that reducing Cbl-b expression in differentiated human effector $\mathrm{T}$ cells improves the functional avidity of these cells by decreasing the amount of antigen required for $\mathrm{T}$ cell activation (Figure 7B). To test whether decreasing Cbl-b expression by specific siRNA resulted in a difference in the ability of $\mathrm{CD}^{+} \mathrm{T}$ cell clones to produce IL-2 in response to antigen, control or Cbl-b2 siRNA-transduced CTLs were stimulated with peptide-pulsed T2 cells, and IL-2 production in the supernatant was measured. While unmodified $\mathrm{CD} 28^{-} \mathrm{CD}^{+}$clones failed to produce IL-2 after antigen stimulation, decreasing Cbl-b via the Cbl-b2 siRNA restored IL-2 secretion in MT-3 cells (Figure 7C). Furthermore, stimulation with APCs pulsed with the CMVpp65 $495-503$ peptide induced the CD28-CD8+ clone with decreased Cbl-b expression to produce approximately $67 \%$ of the IL-2 produced by the same parental clone that had been transduced to re-express CD28 and therefore have an intact costimulatory signal (Figure 7D).

To further evaluate the effect of reducing Cbl-b expression in human effector $\mathrm{T}$ cell clones of other specificities, particularly tumorspecific $T$ cells, we transduced the MART-1/MelanA $26-35^{-}$-specific CD28-CD8 ${ }^{+} \mathrm{T}$ cell clone (SK-111) (2) using retroviral vectors encoding Cbl-b siRNA (Cbl-b2). Similar to the results with CMV-specific $\mathrm{T}$ cell clones, siRNA reduced Cbl-b protein expression approximately
100 fold in SK-111 tumor-specific CTLs (Figure 7E). To test whether reducing Cbl-b expression by siRNA resulted in differences in the ability to recognize tumor cells, parental and Cbl-b2 siRNA-transduced $\mathrm{CD}^{+} \mathrm{T}$ cell clones were incubated with melanoma tumor lines that either express or lack the MART-1 antigen. Cbl-b2 siRNAtransduced $\mathrm{CD}^{+} \mathrm{T}$ cell clones produced increased amounts of IFN- $\gamma$ compared with control $\mathrm{CD}^{+} \mathrm{T}$ cell clones following recognition of the MART-1 expressing 526 melanoma cell line, which expresses HLA-A2 and the MelanA antigen (Figure 7F). Cbl-b2 siRNA-transduced clones did not respond to the melanoma tumor line that did not express the MART-1 antigen (HLA-A2 ${ }^{+} 375$ ), indicating that decreasing Cbl-b expression does not result in spontaneous recognition of tumors without TCR specificity. To test whether decreasing Cbl-b expression by specific siRNA also resulted in a difference in the ability of $\mathrm{CD}^{+} \mathrm{T}$ cell clones to produce IL- 2 in response to antigen, control or Cbl-b2 siRNA-transduced CTLs were stimulated with peptide-pulsed T2 cells, and IL-2 production in the supernatant was measured. Decreasing Cbl-b via the Cbl-b2 siRNA restored IL-2 secretion in MelanA $\mathrm{A}_{26-35^{-}}$-specific CD28-CD8 ${ }^{+} \mathrm{T}$ cell clones (Figure 7G). Furthermore, Cbl-b2 siRNA-transduced cells proliferated in response to antigen without the requirement for supplemental exogenous IL-2, whereas control $\mathrm{CD}^{+} \mathrm{T}$ cell clones required exogenous IL-2 for proliferation (Figure 7E). Thus, targeting Cbl-b in human T cells may provide a means to promote autocrine IL-2 production and $\mathrm{T}$ cell proliferation in effector $\mathrm{CD}^{+} \mathrm{T}$ cells and to reduce the threshold for activation as a means to enhance efficacy of adoptive therapy.

\section{Discussion}

Adoptive $\mathrm{T}$ cell immunotherapy of cancer provides an opportunity to not only use tumor-reactive $\mathrm{T}$ cells for therapy, but also to genetically engineer the $\mathrm{T}$ cells prior to infusion as a means to enhance function and overcome therapeutic obstacles such as the poor immunogenicity of many tumor cells and the limited in vivo survival and function of transferred cells. This study provides the first evidence to our knowledge that abrogating expression of a negative regulator of lymphocyte function, Cbl-b, in effector $\mathrm{CD}^{+} \mathrm{T}$ cells generated by several cycles of in vitro stimulation and expansion can significantly enhance the efficacy of adoptive therapy of a disseminated malignancy. Previous studies of the regulatory role of Cbl-b in T cell function have largely focused on the activity in naive $T$ cells during the primary response to antigen (16-18, 20, 42, 43). Transfer of naive $\mathrm{Cblb}^{-/-} \mathrm{CD}^{+} \mathrm{T}$ cells into tumor-bearing hosts can also lead to efficient eradication of some established tumors $(12,22,44)$. In addition, transfer of a mixture of polyclonal naive and antigen-specific $\mathrm{CD}^{+}$and $\mathrm{CD}^{+} \mathrm{Cblb}^{-/-}$ $\mathrm{T}$ cells that had been acutely activated in vivo transiently mediated tumor destruction in a spontaneous insulinoma model (45). However, these studies, which suggest a potential benefit to ablating Cbl-b in T cells targeting a tumor, are not directly applicable to clinical settings that require extensive in vitro expansion of a small number of tumor-specific $\mathrm{CD}^{+} \mathrm{T}$ cells. In vitro expansion generally induces differentiation to effector cells, which, in contrast to naive $T$ cells, usually have lost the ability to produce IL-2 following target recognition, have reduced proliferative capacity compared with naive $\mathrm{T}$ cells, and become dependent on $\mathrm{CD} 4^{+} \mathrm{T}$ helper cells or exogenous cytokines for proliferation and sustained function (46-51). Our observation that $\mathrm{Cblb}^{-/-}$effector $\mathrm{CD}^{+} \mathrm{T}$ cells retain proliferative capacity suggests that Cbl-b may be an important regulatory checkpoint in the differentiation of $\mathrm{CD}^{+} \mathrm{T}$ cells to become helper dependent. 
Exogenous IL-2 is required for proliferation of in vitro expanded effector T cells and is commonly administered during therapy in humans to promote the survival and expansion of transferred CD8 ${ }^{+}$ $\mathrm{T}$ cells. However, therapeutic administration of this cytokine, often at high doses, can lead to significant toxicities, including a potentially life-threatening capillary leak syndrome $(1,2)$. In the model used in this study, eradication of FBL leukemia requires the transferred $\mathrm{T}$ cells to survive for a minimum of 30 days (24), and, similar to clinical settings (3), in vivo IL-2 administration following cell transfer is essential for T cell survival and tumor eradication (52). Our findings that in vitro expanded $\mathrm{Cblb}^{-/-}$effector cells cured mice of disseminated FBL leukemia in the absence of exogenous IL-2 administration suggests that targeting Cbl-b expression in effector $\mathrm{T}$ cells might facilitate the design of therapy protocols that would no longer require inclusion of potentially toxic IL-2 regimens.

Naive and effector $\mathrm{Cblb}^{-1-} \mathrm{T}$ cells were much less dependent than wild-type $\mathrm{T}$ cells on both autocrine and exogenous IL-2 for proliferation, and Cbl-b was found to not only regulate IL-2 production and the subsequent IL-2-induced proliferation, but also to regulate an IL-2-independent proliferative pathway. Proliferation of resting T lymphocytes depends upon the engagement of TCR and costimulatory pathways, such as CD28. In naive $T$ cells, initiation of $\mathrm{T}$ cell cycling can occur in the absence of IL-2 $(33,35,53)$ but appears to require prolonged TCR/CD28 engagement and the downstream activation of PI3K/PKB, Akt, and mammalian target of rapamycin (36). Cbl-b antagonizes TCR- and CD28-dependent proximal signaling of PI3K/PKB, Akt, and NF- $\mathrm{KB}(18-20,54)$, and the enhanced proliferation of $\mathrm{Cblb}^{-/-} \mathrm{T}$ cells has been shown to be dependent on PI3K (19). Thus, Cbl-b deficiency may be amplifying the IL-2-independent proliferation pathway in effector $\mathrm{T}$ cells by prolonging TCR and CD28 signaling pathways.

Our studies demonstrate that Cbl-b deficiency enhanced both proliferation and survival of effector T cells. In fact, $\mathrm{Cblb}^{-/-}$effector $\mathrm{CD}^{+} \mathrm{T}$ cells did not require CD28 signaling or exogenous IL-2 for proliferation, which is consistent with previous studies that have shown naive $\mathrm{Cblb}^{-/-} \mathrm{CD} 4^{+} \mathrm{T}$ cells are also independent of CD28 costimulation for proliferation $(16,17)$. As far as we know, this is the first study to demonstrate increased survival in $\mathrm{Cblb}^{-/} \mathrm{CD}^{+}$effector cells, suggesting one potential mechanism for the increased efficacy observed in tumor therapy. CD28 was also not required for the enhanced of survival of $\mathrm{Cblb}^{-/-}$effector T cells, which was independent of exogenous IL-2 and associated with increased expression of the CD28-responsive antiapoptotic molecule $\mathrm{Bcl}-\mathrm{xL}(39,55)$. The enhanced survival of $\mathrm{Cblb}^{-/-} \mathrm{T}$ cells was most evident at day 4 after activation, rather than earlier time points, and could reflect Cbl-b-mediated regulation of IL-2 secretion, as addition of exogenous IL-2 rescued wild-type T cells from increased apoptosis.

One concern about transferring tumor/self-reactive $T$ cells with enhanced function into patients is autoimmune toxicity, since most tumor antigens are also self-antigens. While increased autoimmunity has been reported in $\mathrm{Cblb}^{-/-}$mice in which the whole repertoire is deficient in Cbl-b $(16,17)$, no evidence of acute or persistent autoimmune toxicity was detected following transfer of $\mathrm{TCR}_{\mathrm{gag}} \mathrm{Cblb}^{-/-}$ cells into hosts in which the targeted gag tumor antigen was also expressed as a self-antigen in the liver. The safety of $\mathrm{Cblb}^{-/-} \mathrm{T}$ cells in therapy targeting self-proteins may be enhanced by the inability of transferred $\mathrm{Cblb}^{--}$effector $\mathrm{CD}^{+} \mathrm{T}$ cells to form long-term memory cells with self-renewing capacity in the host. Cbl-b has been shown to regulate anergy induction of naive T cells in vitro and in vivo (54,
56-58), and thus long-term persistence of transferred self-reactive $\mathrm{Cblb}^{-/-}$effector $\mathrm{CD}^{+} \mathrm{T}$ cells might pose risks of reactivation and autoimmunity. In our studies, congenically marked transferred $\mathrm{Cblb}^{-/-}$effector cells were rarely detectable by flow cytometry 60 days after transfer. Furthermore, neither immunization of cured mice with Listeria monocytogenes that expressed the gag epitope, nor in vitro expansion of splenocytes from cured mice with antigen and IL-2, resulted in a detectable population of $\mathrm{Cblb}^{-/-}$cells (data not shown). Thus, ablating Cbl-b did not appear to enhance the ability of in vitro-derived effector $T$ cells cultured with antigen and IL-2 to form long-term self-renewing memory cells but rather did act transiently to enhance the proliferation and sustain the survival of the transferred $\mathrm{CD}^{+} \mathrm{T}$ cells through the period required for tumor eradication without causing autoimmunity. Moreover, ablating Cbl-b in tumor-reactive $T$ cells may provide additional benefits for cellular therapy, particularly if targeting tumors of other histologies in which TGF- $\beta$ - and Treg-mediated suppression are known to be important. Naive $\mathrm{Cblb}^{-1-} \mathrm{T}$ cells have been shown to be resistant to both TGF- $\beta$ - and Treg-mediated suppression and to better infiltrate solid tumors $(12,22,42,44,45,59)$, and studies in relevant solid tumor therapy models will need to be performed to determine whether this is also true for effector $\mathrm{CD}^{+} \mathrm{T}$ cells.

CD28 is a critical costimulatory molecule required for the generation of functional T cell-mediated immunity (39). CD28 is expressed on naive $\mathrm{T}$ cells but is generally lost when the small number of naive, potentially tumor-reactive $T$ cells detectable in a patient is expanded by multiple cycles of in vitro stimulation to obtain a high enough number of tumor-reactive effector $T$ cells for adoptive transfer to achieve therapeutic efficacy. Effector T cells that no longer express CD28 exhibit very limited proliferative responses in the absence of exogenous cytokines (21). A previous study in our laboratory demonstrated that genetically modifying human $\mathrm{CD} 28^{-} \mathrm{CD} 8^{+}$ antigen-specific effector $\mathrm{T}$ cells to reconstitute CD28 expression restored their capacity to produce IL-2 following target recognition and to induce autocrine-regulated proliferation (21). In this study, we identified an alternative approach to restore the capacity to induce IL-2 and proliferation by human effector memory CD28$\mathrm{T}$ cells following target recognition by transducing 2 different human effector $\mathrm{CD} 28^{-} \mathrm{CD} 8^{+}$effector $\mathrm{T}$ cell clones with siRNAs that specifically target Cbl-b. Reducing Cbl-b expression in the relatively low-avidity MelanA-specific clones restored IL-2 production and autocrine proliferation in the absence of exogenous IL-2, functions that could likely render these genetically modified tumor-reactive cells more effective in adoptive immunotherapy. Reducing Cbl-b protein expression either approximately 10 or 100 fold in higher avidity CMV-specific T cell clones was sufficient to achieve a similar benefit as restoring CD28 expression on IL-2 production but had the benefit of not requiring that the target cell being recognized express a matching costimulatory ligand. Moreover, reducing Cbl-b expression with siRNA reduced the threshold for activation, making it possible for effector $\mathrm{T}$ cells to respond to targets expressing lower amounts of the selected antigen, which represents a common evasion strategy observed with tumors (60). Thus, targeting Cbl-b expression in human $\mathrm{T}$ cells with siRNA appears to represent a clinically feasible approach to improve the therapeutic activity of effector $\mathrm{T}$ cells that could be administered to treat human malignancies.

\section{Methods}

Mice. Alb/gag and $\mathrm{TCR}_{\text {gag }}$ transgenic mice have been previously described $(25,26)$. $\mathrm{Cblb}^{-/}$mice were originally received from Hua Gu (Columbia 
University) and crossed to $\mathrm{TCR}_{\text {gag }}$ and $\mathrm{TCR}_{\mathrm{gag}} \mathrm{CD} 28^{-/-}$mice in our animal facility. Thy $1.1 \mathrm{C} 57 \mathrm{BL} / 6$ and $\mathrm{Il2}{ }^{+/-}$mice were obtained from The Jackson Laboratory. The $\mathrm{Il}^{+/-}$mice were crossed to $\mathrm{TCR}_{\mathrm{gag}}$ and $\mathrm{TCR}_{\mathrm{gag}} \mathrm{Cblb}^{-/-}$mice in our animal facility to generate $\mathrm{TCR}_{\mathrm{gag}} \mathrm{Il} 2^{+/-}$and $\mathrm{TCR}_{\mathrm{gag}} \mathrm{Cblb}^{-/-} \mathrm{Il}^{-/-}$mice. All mice were maintained under specific pathogen-free conditions. Our murine studies were executed according to our approved animal protocol and the policies of the Institute for Animal Care and Use Committee in the Department of Comparative Medicine, University of Washington.

Cell lines, antibodies, and peptides. FBL, a Friend virus-induced erythroleukemia of C57BL/6 $\left(\mathrm{H}-2^{\mathrm{b}}\right)$ origin that expresses MHC class I and FMuLV Gag-encoded products, has been previously described (61). The FMuLV Gag peptide (CCLCLTVFL) recognized by $\mathrm{TCR}_{\mathrm{gag}} \mathrm{CD}^{+} \mathrm{T}$ cells was purchased from Pi Proteomics. The fluorochrome-conjugated antibodies CD8, Thy1.1, CD44, CD25, CD69, CD62L, Bcl-2, IL-2, and IFN- $\gamma$ and the mouse Th1/Th2 cytobead arrays were purchased from BD Biosciences. The neutralizing mouse IL-2-specific antibodies, blocking antibodies to IL-2R $\alpha$ (CD25), and recombinant murine IL-2 were purchased from R\&D Systems. Rabbit anti-mouse Bcl-xL and antibodies to phospho-Stat 5 (Tyr694) were purchased from Cell Signaling Technologies, and intracellular staining was detected via secondary labeling with anti-rabbit 546 (Invitrogen). The Annexin-V Staining kit was obtained from BD Biosciences, and all intracellular staining assays were performed using the BD Biosciences Fix/ Perm Kit. The gag/H-2D tetramer was synthesized by the Immune Monitoring Core at the Fred Hutchinson Cancer Research Center. The IL-2dependent cell line (CTLL-2 cells) has been previously described (37) and was maintained in vitro by culture with $50 \mathrm{U} / \mathrm{ml} \mathrm{IL-2}$.

Generation of in vitro-derived effector $T C R_{\text {gag }}$ cells. $\mathrm{CD}^{+} \mathrm{T}$ cells were purified from the spleens of naive transgenic mice by negative selection using $\mathrm{CD}^{+}$ isolation kit (Dynal). $\mathrm{TCR}_{\mathrm{gag}} \mathrm{Cblb}^{+/}, \mathrm{TCR}_{\mathrm{gag}} \mathrm{Cblb}^{-/}, \mathrm{TCR}_{\mathrm{gag}} \mathrm{Il} 2^{-/,}, \mathrm{TCR}_{\mathrm{gag}} \mathrm{Cblb}^{-/}$ $\mathrm{Il} 2^{--}, \mathrm{TCR}_{\mathrm{gag}} \mathrm{CD} 28^{---}$, and $\mathrm{TCR}_{\mathrm{gag}} \mathrm{Cblb}^{-/-} \mathrm{CD} 28^{-/-} \mathrm{T}$ cell lines were generated as previously described (25). Briefly, $1 \times 10^{6}$ transgenic T cells were cultured with $5 \times 10^{6}$ irradiated, syngeneic feeders cells, $3 \times 10^{6}$ irradiated FBL leukemia, and r-h-IL-2 $(25 \mathrm{U} / \mathrm{ml})$ in $10 \mathrm{ml}$ of complete media (RPMI 1640 supplemented with $2 \mu \mathrm{M}$ glutamine, $100 \mathrm{U} / \mathrm{ml}$ penicillin/streptomycin, $10 \%$ fetal calf serum, and $30 \mu \mathrm{M} 2$-mercaptoethanol). $\mathrm{CD}^{+} \mathrm{T}$ cells were stimulated every 7 days, using the same protocol. Five days after the third in vitro stimulation with antigen, in vitro-derived effector $\mathrm{T}$ cells were used in various assays or transferred for adoptive immunotherapy.

Tcell proliferation assays. CD8 ${ }^{+}$transgenic T cells were labeled with $1 \mu \mathrm{g} / \mathrm{ml}$ CFSE for 30 minutes at $37^{\circ} \mathrm{C}$. A total of $1 \times 10^{5}$ CFSE-labeled transgenic $\mathrm{CD}^{+} \mathrm{T}$ cells were incubated in round-bottom 96 -well plates with syngeneic splenocytes $\left(5 \times 10^{5}\right)$ that had been pulsed with titrating concentrations of gag peptide. CFSE dilution of transgenic T cells was assessed using flow cytometry by gating on Thy $1.2^{+} \mathrm{CD}^{+}$cells. To block IL-2, neutralizing antibodies to mouse IL-2 and blocking antibodies to CD25 were included in the assay by adding the antibodies $(20 \mu \mathrm{g} / \mathrm{ml})$ to $\mathrm{T}$ cell cultures 1 hour prior to activation with antigen.

Intracellular staining for cytokines, Bcl-2, Bcl-xL, phospho-Stat5. For intracellular cytokine staining, naive or in vitro-derived effector transgenic $T$ cells were incubated with peptide-pulsed congenic splenocytes for 5 hours in the presence of monensin. Cells were then labeled with antibodies to CD8 and Thy1.2, fixed and subsequently permeabilized, and stained with antibodies to mouse IL- 2 and IFN- $\gamma$ according to the manufacturer's directions (BD Biosciences). Phospho-Stat5 staining was detected with anti-rabbit 546 on fixed and permeabilized cells 24 hours after $T$ cell activation with antigen using BD Biosciences Fix/Perm buffers. Bcl-2 and Bcl-xL staining was performed on day 4 after $T$ cell activation with antigen, also using BD Biosciences Fix/Perm buffers. Anti-Bcl-2 was directly conjugated to FITC, and an anti-rabbit 546 antibody was used to detect Bcl-xL. Annexin- $V$ and $7 \mathrm{AAD}$ staining was performed on day 4 after in vitro activation according to the manufacture's protocol (BD Biosciences). Stained cells were analyzed by flow cytometry.

Adoptive immunotherapy of disseminated FBL lenkemia. Adoptive immunotherapy experiments were performed as previously described $(25,27)$. Briefly, C57BL/6 Thy1.1 or Alb/gag Thy1.1 recipient mice were inoculated with $5 \times 10^{6}$ live FBL leukemic cells by intraperitoneal injection. Five days later, after the leukemia was disseminated, mice received cyclophosphamide (180 $\mathrm{mg} / \mathrm{kg}$ ), followed 5 hours later - to permit clearance of the cyclophosphamide - by injection of the indicated number of in vitro-derived effector Thy $1.2^{+} \mathrm{TCR}_{\text {gag }} \mathrm{Cblb}^{+/}$, $\mathrm{TCR}_{\mathrm{gag}} \mathrm{Cblb}^{-/}$, $\mathrm{TCR}_{\mathrm{gag}} \mathrm{CD} 28^{-/-}$, or $\mathrm{TCR}_{\mathrm{gag}} \mathrm{Cblb}^{-/-}$ $\mathrm{CD} 28^{-/-} \mathrm{T}$ cells. Some recipients also received IL-2 injections for 10 days $\left(1 \times 10^{4} \mathrm{U} / \mathrm{ml} / \mathrm{mouse} / \mathrm{d}\right)$. Mice were monitored for ascites formation or nodal masses (as an indicator of tumor burden) and euthanized if the detectable tumor burden increased to a size that predictably led to mortality within $24-48$ hours. T cell persistence and function was monitored by bleeding mice and sacrificing cohorts of mice at various time points and analyzing for Thy $1.2^{+} \mathrm{CD}^{+} \mathrm{T}$ cells by flow cytometry.

Immunohistochemistry and microscopy of liver sections. Seven $\mu \mathrm{M}$ frozen liver sections were stained with primary antibodies to rat anti-mouse CD8 (BD Biosciences) and with secondary anti-rat-488 antibodies and counterstained with DAPI (Invitrogen). A total of 12 sections from 3-4 mice per group were compared by analysis on a Leica fluorescence microscope. Photographic images were captured using a fluorescence microscope equipped with a digital camera (Orca-ER) and assembled into RGB images with Adobe Photoshop.

Transduction of MelanA- and CMV-specific CD $8^{+} T$ cell clones with retroviruses expressing Cbl-b siRNA. Putative Cbl-b siRNA sequences (21-nt long, initial aa motif, $\sim 50 \%$ GC) homologous between human and mouse were predicted and synthesized by Genscript and cloned into the PQCXIH retroviral construct (Clontech). EGFP (Clontech) was subsequently cloned into the multiple cloning sites to generate PQEGFPXIH-siRNA vectors containing the following siRNA hairpin sequences: Cbl-b1, 5'-AAAGTGGTAAGACTGTGCCAA-(TTGATATCCG)-TTGGCACAGTCTTACCACTTT-3'; Cbl-b2, 5'-AACACAGACGCCATGATTTGC-(TTGATATCCG)-GCAAATCATGGCGTCTGTGTT-3'; and Cbl-b3, 5'-AAGATGTCAAGATTGAGCCTT(TTGATATCCG)-AAGGCTCAATCTTGACATCTT- $3^{\prime}$. The sequence in parenthesis is the hairpin loop that is included in all of the siRNA constructs. Retroviral constructs were transiently transfected into the PhoenixGALV packaging cell line by calcium phosphate transfection as previously described (21). Supernatants from transfected Phoenix-GALV packaging cells were collected on days 2 and 3 after transfection and concentrated by ultracentrifugation. The human MT-3 CMVpp65-specific CD8 ${ }^{+} \mathrm{T}$ cell clone was produced in our laboratory by Max Topp, and the SK-111 CTL line was provided by Cassian Yee (Fred Hutchinson Cancer Research Center). MT-3 or SK-111 cells were stimulated with anti-CD3 (OKT-3) and IL-2 (50 $\mathrm{U} / \mathrm{ml}$ ) and transduced with concentrated retroviral supernatants on day 3 of expansion by spinfection $\left(1,000 \mathrm{~g}, 1\right.$ hour, $\left.32^{\circ} \mathrm{C}\right)$ in the presence of polybrene $(8 \mu \mathrm{g} / \mathrm{ml})$. EGFP ${ }^{+}$CTLs were sorted on a FACSVantage flow cytometer and reexpanded with anti-CD3 and IL-2. Cbl-b protein expression levels were assessed by Western blot using anti-Cbl-b (clone G, Santa Cruz Biosciences Inc.) or anti-actin (C-2, Santa Cruz Biosciences Inc.) antibodies and detected with HRP-linked goat anti-mouse Ig secondary antibody.

Cytokine production and functional avidity of $C D 8^{+} T$ cell clones. To measure IFN- $\gamma$ and IL-2 production, expanded control or Cbl-b2 siRNA-transduced

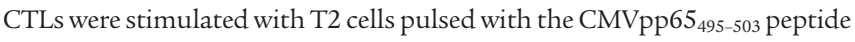
(NLVPMVATV) or the MelanA $A_{26-35}$ peptide analog (ELAGIGILTV), which binds stably to HLA-A*02, at the indicated concentrations or with the HLA-A2 ${ }^{+}$melanoma cells A375 (MelanA $\left.A_{26-35^{-}}\right)$or Mel $526\left(\right.$ MelanA $\left._{26-35^{+}}\right)$. Cytokine production was measured by standard ELISA or by cytokine bead Array (BD Biosciences) on a FACSCanto flow cytometer. To mea- 
sure proliferation, expanded control or Cbl-b2 siRNA-transduced CTLs were stimulated with mitomycin-c-treated $\mathrm{T} 2$ cells pulsed with the indicated peptide concentrations, and proliferation was measured on day 3 by pulsing with ${ }^{3} \mathrm{H}$-thymidine.

Statistics. Results are displayed as mean \pm SEM. Statistical differences between groups were determined using a 2-tailed unpaired Student's $t$ test, where a $P$ value less than 0.05 was considered significant, except for those in Figure $5 \mathrm{~A}$, where analyses of survival curves were performed using a log-rank Mantel-Cox test.

\section{Acknowledgments}

We thank C. Chou, C. Fowler, A. Schietinger, and T.D. Kim for helpful discussion and C. Georgopolos and I. Roberts for technical support. This work was supported in part by grants K01 CA117985-01 and R37 CA33084 from the United States National Institute of Health and a grant from the Leukemia and Lymphoma Society. Support was also received from a Korean GRL program grant from KRIBB. I.M. Stromnes was supported by Training Basic and Physician Scientists in Immunology Training grant 5T32AI007411.

Received for publication January 27, 2010, and accepted in revised form July 28, 2010.

Address correspondence to: Philip Greenberg, Immunology \& Medicine, University of Washington, H-461 Health Sciences Building, Campus Box 356425, Seattle, Washington 981956425, USA. Phone: 206.543.8306; Fax: 206.221.2796; E-mail: pgreen@u.washington.edu.
1. Rosenberg SA, Restifo NP, Yang JC, Morgan RA, Dudley ME. Adoptive cell transfer: a clinical path to effective cancer immunotherapy. Nat Rev Cancer. 2008;8(4):299-308.

2. Yee $\mathrm{C}$, et al. Adoptive $\mathrm{T}$ cell therapy using antigen-specific CD8+ T cell clones for the treatment of patients with metastatic melanoma: in vivo persistence, migration, and antitumor effect of transferred T cells. Proc Natl Acad Sci U S A. 2002; 99(25):16168-16173

3. Ho WY, Blattman JN, Dossett ML, Yee C, Greenberg PD. Adoptive immunotherapy: engineering $\mathrm{T}$ cell responses as biologic weapons for tumor mass destruction. Cancer Cell. 2003;3(5):431-437.

4. Blattman JN, Greenberg PD. Cancer immunotherapy: a treatment for the masses. Science. 2004, 305(5681):200-205.

5. Berger C, Turtle CJ, Jensen MC, Riddell SR. Adoptive transfer of virus-specific and tumor-specific T cell immunity. Curr Opin Immunol. 2009;21(2):224-232

6. Schumacher TN, Restifo NP. Adoptive T cell therapy of cancer. Curr Opin Immunol. 2009;21(2):187-189.

7. Dudley ME, Rosenberg SA. Adoptive-cell-transfer therapy for the treatment of patients with cancer. Nat Rev Cancer. 2003;3(9):666-675.

8. Cheng LE, Greenberg PD. Selective delivery of augmented IL-2 receptor signals to responding CD8+ $\mathrm{T}$ cells increases the size of the acute antiviral response and of the resulting memory $\mathrm{T}$ cell pool. J Immunol. 2002;169(9):4990-4997.

9. Ma A, Koka R, Burkett P. Diverse functions of IL-2, IL-15, and IL-7 in lymphoid homeostasis. Annu Rev Immunol. 2006;24:657-679.

10. Ahmadzadeh M, Rosenberg SA. IL-2 administration increases CD4+ CD25(hi) Foxp3+ regulatory T cells in cancer patients. Blood. 2006;107(6):2409-2414.

11. Zou W, Chen L. Inhibitory B7-family molecules in the tumour microenvironment. Nat Rev Immunol. 2008;8(6):467-477.

12. Loeser $\mathrm{S}$, et al. Spontaneous tumor rejection by cbl-b-deficient CD8+ T cells. J Exp Med. 2007; 204(4):879-891.

13. Lin AE, Mak TW. The role of E3 ligases in autoimmunity and the regulation of autoreactive $\mathrm{T}$ cells. Curr Opin Immunol. 2007;19(6):665-673.

14. Teague RM, et al. Peripheral CD8+ T cell tolerance to self-proteins is regulated proximally at the $\mathrm{T}$ cell receptor. Immunity. 2008;28(5):662-674.

15. Zheng Y, Zha Y, Gajewski TF. Molecular regulation of T-cell anergy. EMBO Rep. 2008;9(1):50-55.

16. Bachmaier K, et al. Negative regulation of lymphocyte activation and autoimmunity by the molecular adaptor Cbl-b. Nature. 2000;403(6766):211-216

17. Chiang YJ, et al. Cbl-b regulates the CD28 dependence of T-cell activation. Nature. 2000;403(6766):216-220.

18. Krawczyk C, et al. Cbl-b is a negative regulator of receptor clustering and raft aggregation in $\mathrm{T}$ cells. Immunity. 2000;13(4):463-473.

19. Fang D, Liu YC. Proteolysis-independent regula- tion of PI3K by Cbl-b-mediated ubiquitination in T cells. Nat Immunol. 2001;2(9):870-875.

20. Qiao G, et al. T-cell receptor-induced NF-kappaB activation is negatively regulated by $\mathrm{E} 3$ ubiquitin ligase Cbl-b. Mol Cell Biol. 2008;28(7):2470-2480.

21. Topp MS, Riddell SR, Akatsuka Y, Jensen MC, Blattman JN, Greenberg PD. Restoration of CD28 expression in CD28- CD8+ memory effector T cells reconstitutes antigen-induced IL-2 production. J Exp Med. 2003;198(6):947-955.

22. Chiang JY, Jang IK, Hodes R, Gu H. Ablation of Cbl-b provides protection against transplanted and spontaneous tumors. J Clin Invest. 2007; 117(4):1029-1036.

23. Riddell SR, Greenberg PD. The use of anti-CD3 and anti-CD28 monoclonal antibodies to clone and expand human antigen-specific T cells. J Immunol Methods. 1990;128(2):189-201.

24. Greenberg PD, Cheever MA, Fefer A. Detection of early and delayed antitumor effects following curative adoptive chemoimmunotherapy of established leukemia. Cancer Res. 1980;40(12):4428-4432.

25. Ohlen C, Kalos M, Hong DJ, Shur AC, Greenberg PD. Expression of a tolerizing tumor antigen in peripheral tissue does not preclude recovery of high-affinity CD8+ T cells or CTL immunotherapy of tumors expressing the antigen. J Immunol. 2001; 166(4):2863-2870.

26. Ohlen C, et al. CD8(+) T cell tolerance to a tumorassociated antigen is maintained at the level of expansion rather than effector function. J Exp Med. 2002; 195(11):1407-1418.

27. Dossett ML, et al. Adoptive immunotherapy of disseminated leukemia with TCR-transduced, CD8 $(+)$ $\mathrm{T}$ cells expressing a known endogenous TCR. $\mathrm{Mol}$ Ther. 2009;17(4):742-749.

28. Teague RM, Tempero RM, Thomas S, MuraliKrishna K, Nelson BH. Proliferation and differentiation of CD8+ T cells in the absence of IL-2/15 receptor beta-chain expression or Stat 5 activation. J Immunol. 2004;173(5):3131-3139.

29. Krawczyk CM, et al. Differential control of CD28regulated in vivo immunity by the E3 ligase Cbl-b. J Immunol. 2005;174(3):1472-1478.

30. Zhang Y, et al. Reversal of P-glycoprotein-mediated multi-drug resistance by the E3 ubiquitin ligase Cbl-b in human gastric adenocarcinoma cells. JPathol. 2009;218(2):248-255.

31. Ruben $S$, et al. Cellular transcription factors and regulation of IL-2 receptor gene expression by HTLV-I tax gene product. Science. 1988;241(4861):89-92.

32. Lopez-Cabrera M, Munoz E, Blazquez MV, Ursa MA, Santis AG, Sanchez-Madrid F. Transcriptional regulation of the gene encoding the human C-type lectin leukocyte receptor AIM/CD69 and functional characterization of its tumor necrosis factor-alpha-responsive elements. J Biol Chem. 1995;270(37):21545-21551.

33. Kundig TM, Schorle H, Bachmann MF, Hen- gartner H, Zinkernagel RM, Horak I. Immune responses in interleukin-2-deficient mice. Science. 1993;262(5136):1059-1061.

34. Williams MA, Tyznik AJ, Bevan MJ. Interleukin-2 signals during priming are required for secondary expansion of CD8+ memory T cells. Nature. 2006;441(7095):890-893.

35. Appleman LJ, Berezovskaya A, Grass I, Boussiotis VA. CD28 costimulation mediates T cell expansion via IL-2-independent and IL-2-dependent regulation of cell cycle progression. J Immunol. 2000; 164(1):144-151.

36. Colombetti S, Basso V, Mueller DL, Mondino A. Prolonged TCR/CD28 engagement drives IL-2independent $\mathrm{T}$ cell clonal expansion through signaling mediated by the mammalian target of rapamycin. J Immunol. 2006;176(5):2730-2738.

37. Lord JD, McIntosh BC, Greenberg PD, Nelson BH. The IL-2 receptor promotes proliferation, bcl-2 and bcl-x induction, but not cell viability through the adapter molecule Shc. I Immunol. 1998; 161(9):4627-4633.

38. Lord JD, McIntosh BC, Greenberg PD, Nelson BH. The IL-2 receptor promotes lymphocyte proliferation and induction of the c-myc, bcl-2, and bcl-x genes through the trans-activation domain of Stat5. J Immunol. 2000;164(5):2533-2541.

39. Acuto O, Michel F. CD28-mediated co-stimulation: a quantitative support for TCR signalling. Nat Rev Immunol. 2003;3(12):939-951.

40. Greenberg PD, Cheever MA. Treatment of disseminated leukemia with cyclophosphamide and immune cells: tumor immunity reflects long-term persistence of tumor-specific donor T cells. J Immunol. 1984;133(6):3401-3407.

41. Azuma M, Phillips JH, Lanier LL. CD28- T lymphocytes. Antigenic and functional properties. J Immunol. 1993;150(4):1147-1159.

42. Wohlfert EA, Callahan MK, Clark RB. Resistance to $\mathrm{CD} 4+\mathrm{CD} 25$ + regulatory $\mathrm{T}$ cells and TGF-beta in Cbl-b-/- mice. J Immunol. 2004;173(2):1059-1065.

43. Zhang R, Zhang N, Mueller DL. Casitas B-lineage lymphoma $\mathrm{b}$ inhibits antigen recognition and slows cell cycle progression at late times during CD4+ T cell clonal expansion. J Immunol. 2008; 181(8):5331-5339.

44. Yang T, et al. Mammary tumors with diverse immunological phenotypes show differing sensitivity to adoptively transferred CD8 $+\mathrm{T}$ cells lacking the Cbl-b gene. Cancer Immunol Immunother. 2009; 58(11):1865-1875.

45. Pellegrini M, et al. Adjuvant IL-7 antagonizes multiple cellular and molecular inhibitory networks to enhance immunotherapies. Nat Med. 2009; 15(5):528-536.

46. Keene JA, Forman J. Helper activity is required for the in vivo generation of cytotoxic T lymphocytes. J Exp Med. 1982;155(3):768-782.

47. Kirberg J, Bruno L, von Boehmer H. CD4+8- help 
prevents rapid deletion of CD8+ cells after a transient response to antigen. Eur J Immunol. 1993. 23(8):1963-1967.

48. Matloubian M, Concepcion RJ, Ahmed R. CD4+ T cells are required to sustain CD8+ cytotoxic T-cell responses during chronic viral infection. J Virol. 1994;68(12):8056-8063.

49. Cardin RD, Brooks JW, Sarawar SR, Doherty PC. Progressive loss of CD8+ T cell-mediated control of a gamma-herpesvirus in the absence of CD4+ T cells. J Exp Med. 1996;184(3):863-871.

50. Ossendorp F, Mengede E, Camps M, Filius R, Melief CJ. Specific T helper cell requirement for optimal induction of cytotoxic T lymphocytes against major histocompatibility complex class II negative tumors. J Exp Med. 1998;187(5):693-702.

51. Deeths MJ, Kedl RM, Mescher MF. CD8+ T cells become nonresponsive (anergic) following activation in the presence of costimulation.J Immunol.
1999;163(1):102-110.

52. Cheever MA, Thompson DB, Klarnet JP, Greenberg $\mathrm{PD}$. Antigen-driven long term-cultured T cells proliferate in vivo, distribute widely, mediate specific tumor therapy, and persist long-term as functional memory T cells. J Exp Med. 1986;163(5):1100-1112.

53. Khoruts A, Mondino A, Pape KA, Reiner SL, Jenkins MK. A natural immunological adjuvant enhances T cell clonal expansion through a CD28-dependent, interleukin (IL)-2-independent mechanism. J Exp Med. 1998;187(2):225-236.

54. Jeon MS, et al. Essential role of the E3 ubiquitin ligase Cbl-b in T cell anergy induction. Immunity. 2004;21(2):167-177.

55. Boise LH, Gottschalk AR, Quintans J, Thompson $\mathrm{CB}$. Bcl-2 and Bcl-2-related proteins in apoptosis regulation. Curr Top Microbiol Immunol. 1995; 200:107-121.

56. Heissmeyer V, et al. Calcineurin imposes T cell unre- sponsiveness through targeted proteolysis of signaling proteins. Nat Immunol. 2004;5(3):255-265.

57. Chiodetti L, Choi S, Barber DL, Schwartz RH. Adaptive tolerance and clonal anergy are distinct biochemical states. J Immunol. 2006;176(4):2279-2291.

58. St Rose MC, et al. The E3 ubiquitin ligase Cbl-b regulates expansion but not functional activity of self-reactive CD4 T cells. J Immunol. 2009;183(8):4975-4983.

59. Wohlfert EA, Gorelik L, Mittler R, Flavell RA, Clark RB. Cutting edge: deficiency in the E3 ubiquitin ligase Cbl-b results in a multifunctional defect in T cell TGF-beta sensitivity in vitro and in vivo. JImmunol. 2006;176(3):1316-1320.

60. Zang X, Allison JP. The B7 family and cancer therapy: costimulation and coinhibition. Clin Cancer Res. 2007;13(18 pt 1):5271-5279.

61. Teague RM, et al. Interleukin-15 rescues tolerant CD8+ T cells for use in adoptive immunotherapy of established tumors. Nat Med. 2006;12(3):335-341. 